\title{
BVOC ecosystem flux measurements at a high latitude wetland site
}

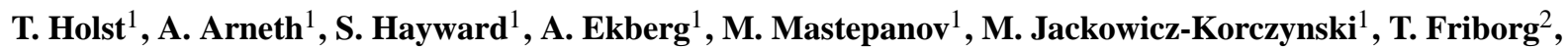 \\ P. M. Crill ${ }^{3}$, and K. Bäckstrand ${ }^{3}$ \\ ${ }^{1}$ Department of Physical Geography and Ecosystems Analysis, Lund University, Sweden \\ ${ }^{2}$ Department of Geography and Geology, University of Copenhagen, Denmark \\ ${ }^{3}$ Department of Geology and Geochemistry, Stockholm University, Sweden
}

Received: 13 October 2008 - Published in Atmos. Chem. Phys. Discuss.: 18 December 2008

Revised: 21 January 2010 - Accepted: 28 January 2010 - Published: 15 February 2010

\begin{abstract}
In this study, we present summertime concentrations and fluxes of biogenic volatile organic compounds (BVOCs) measured at a sub-arctic wetland in northern Sweden using a disjunct eddy-covariance (DEC) technique based on a proton transfer reaction mass spectrometer (PTR-MS). The vegetation at the site was dominated by Sphagnum, Carex and Eriophorum spp. The measurements reported here cover a period of 50 days (1 August to 19 September 2006), approximately one half of the growing season at the site, and allowed to investigate the effect of day-to-day variation in weather as well as of vegetation senescence on daily BVOC fluxes, and on their temperature and light responses. The sensitivity drift of the DEC system was assessed by comparing $\mathrm{H}_{3} \mathrm{O}^{+}$-ion cluster formed with water molecules $\left(\mathrm{H}_{3} \mathrm{O}^{+}\left(\mathrm{H}_{2} \mathrm{O}\right)\right.$ at m37) with water vapour concentration measurements made using an adjacent humidity sensor, and the applicability of the DEC method was analysed by a comparison of sensible heat fluxes for high frequency and DEC data obtained from the sonic anemometer. These analyses showed no significant PTR-MS sensor drift over a period of several weeks and only a small flux-loss due to high-frequency spectrum omissions. This loss was within the range expected from other studies and the theoretical considerations.
\end{abstract}

Standardised $\left(20^{\circ} \mathrm{C}\right.$ and $\left.1000 \mu \mathrm{mol} \mathrm{m}^{-2} \mathrm{~s}^{-1} \mathrm{PAR}\right)$ summer isoprene emission rates found in this study of $329 \mu \mathrm{g} \mathrm{C} \mathrm{m}{ }^{-2}$ (ground area) $\mathrm{h}^{-1}$ were comparable with findings from more southern boreal forests, and fen-like ecosystems. On a diel scale, measured fluxes indicated a stronger temperature dependence than emissions from temperate or (sub)tropical ecosystems. For the first time, to our knowledge, we report ecosystem methanol fluxes from a sub-arctic

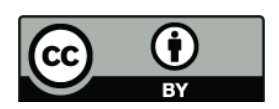

Correspondence to: T. Holst (thomas.holst@nateko.lu.se) ecosystem. Maximum daytime emission fluxes were around $270 \mu \mathrm{g} \mathrm{m}^{-2} \mathrm{~h}^{-1}$ (ca. $100 \mu \mathrm{g} \mathrm{C} \mathrm{m}^{-2} \mathrm{~h}^{-1}$ ), and during most nights small negative fluxes directed from the atmosphere to the surface were observed.

\section{Introduction}

The global emission of biogenic volatile organic compounds (BVOC) from terrestrial vegetation is estimated to be ca. $1000 \mathrm{Tg} \mathrm{Ca}^{-1}$ (e.g. Guenther et al., 1995; Lathière et al., 2006; Seco et al., 2007) with an associated strong impact on atmospheric chemistry. BVOC consume or produce tropospheric ozone, depending on atmospheric physicochemical conditions like the levels of $\mathrm{NO}_{\mathrm{x}}$, and influence the levels of $\mathrm{OH}$ and hence methane lifetime (Derwent et al., 1995; Atkinson, 2000; Poisson et al., 2000; Ortega et al., 2007). BVOCs are also known to initiate and foster the production of secondary organic aerosols (SOA, Hoffmann et al., 1997; O'Dowd et al., 2002; Kulmala et al., 2004) that scatter and absorb radiation and act as cloud condensation nuclei. Despite their importance for global chemistry and climate, many processes relating to the physiology and atmospheric reactions of BVOCs remain poorly understood. Large uncertainties are introduced not only by the poorly quantified source and sink distribution, but also by an incomplete understanding of ecological and physiological controls beyond the short-term dependency on light and temperature (Niinemets et al., 2004; Arneth et al., 2008a). Furthermore, it has been shown that some VOC can react very rapidly after emission to form a sink for oxidants which has not been previously accounted for (Di Carlo et al., 2004; Holzinger et al., 2005; Karl et al., 2008). These highly reactive VOCs might be a defence mechanism for plants against atmospheric oxidants

Published by Copernicus Publications on behalf of the European Geosciences Union. 
and their oxidation products may act on a larger scale due to their relatively high stability and thus contribute effectively to SOA production (Holzinger et al., 2005).

Leaf BVOC emissions have been measured from a wide range of vegetation types and species (e.g. Kesselmeier and Staudt, 1999; Seco et al., 2007), but the data are mostly restricted to relatively short-term campaigns using leaf or branch cuvette techniques. A number of studies have investigated the canopy-atmosphere exchange of BVOC using the concentration gradient method, relaxed eddy accumulation (REA) methods, as well as disjunct eddy covariance techniques (DEC, Gallagher et al., 2000; Rinne et al., 2000, 2001; Schade and Goldstein, 2001) and, in the case of isoprene, direct eddy covariance with fast response sensors (Rinne et al., 2002; Pressley et al., 2005). Recently, the development of the proton transfer mass spectrometer (Lindinger et al., 1998; de Gouw et al., 2003; de Gouw and Warneke, 2007), in conjunction with disjunct eddy covariance techniques has led to an increased availability of flux data from a wider range of ecosystems including tropical and mid-latitude forests, grassland and crops (e.g. Karl et al., 2001, 2002; Grabmer et al., 2004; Brunner et al., 2007; Custer and Schade, 2007) and covering continuously periods from days to weeks. These measurements have drawn attention to the large temporal and spatial variability in ecosystem emission rates. Even within similar vegetation classes, maximum emissions can vary by a factor of ten or more, depending on the species composition (Rinne et al., 2000; Karl et al., 2003; Pressley et al., 2005), while measurements that covered an entire growing season or longer point to a significant influence of changing atmospheric conditions, or growth stages or decay of vegetation on the emission of VOCs from different ecosystems (Fuentes et al., 1999; Westberg et al., 2000; Karl et al., 2003; Pressley et al., 2005; Brunner et al., 2007). Canopy flux data from a wide range of vegetation types and climates are thus crucial to evaluate process descriptions and emission rates calculated with regional and global BVOC emission models. To do so BVOC flux measurements should ideally span not only short-term campaigns but also inform on, at least, seasonal, better interannual variability (Pressley et al., 2005). Furthermore, ecosystem carbon and water fluxes measured side-byside with BVOC flux emissions (e.g. Gallagher et al., 2000; Simon et al., 2005) are valuable information to illuminate flux controls on ecosystem scale and to quantify all gaseous carbon fluxes exchanged with the atmosphere.

One region for which virtually no information on BVOC emissions exist are the high northern latitudes - ecosystems that are likely to experience warming, permafrost melting and changes in vegetation distribution in the coming decades. Global emission models attribute only a small percentage of total BVOC emissions, mainly of isoprene and monoterpenes, to latitudes above ca. $50^{\circ} \mathrm{N}$, due to the short summers with relatively cool temperatures, and due to vegetation with (particularly in case of isoprene) low emission potentials (Guenther et al., 1995; Arneth et al., 2008b). However, regionally these emissions are important as, for example, emissions from boreal forests have been shown to contribute to growth of aerosol particles and to affect total aerosol mass (Kulmala et al., 2000, 2004; Tunved et al, 2006).

With the exception of a very few studies (Rinne et al., 2000, 2005; Haapanala et al., 2006), most work on BVOC emissions in boreal ecosystems has been done using chamber or microcosm techniques (Janson et al., 1999; Hellén et al., 2006; Tiiva et al., 2007a, b; Bäckstrand et al., 2008; Ekberg et al., 2009). Here, we present for the first time DECmeasurements of BVOC exchange between the atmosphere and a sub-arctic wetland, underlain by discontinuous permafrost.

Our objectives here are to present the general performance of the BVOC measurement system as well as a first analysis of BVOC data covering nearly one half of the short growing season. The measurements have been taken as part of a collaborative project on the full gaseous C-balance $\left(\mathrm{CO}_{2}\right.$, $\mathrm{CH}_{4}$ and BVOC) on leaf, microcosm and ecosystem scale in a system that currently undergoes fast permafrost melting.

\section{Methods}

\subsection{Experimental site}

Measurements were made in a sub-arctic wetland ecosystem in Northern Sweden, about $200 \mathrm{~km}$ north of the Arctic Circle, during a 50 day period in 2006 representing the second half of the short growing season. Stordalen mire $\left(68^{\circ}\right.$ $20^{\prime} \mathrm{N}, 19^{\circ} 03^{\prime} \mathrm{E}, 351 \mathrm{~m}$ a.s.l.) is located $10 \mathrm{~km}$ east of the Abisko Scientific Research Station. The mean annual air temperature in Abisko (1913-2003) is $-0.7^{\circ} \mathrm{C}$. The warmest month is July with a mean air temperature of $+11^{\circ} \mathrm{C}(1961-$ 1990, www.ans.kiruna.se). On a long term basis, $304 \mathrm{~mm}$ of precipitation are recorded at this location annually, and the growing season is short (ca. mid May to mid September). The microtopography at the experimental site is quite variable, with slightly elevated drier areas that are underlain by permafrost (called palsas) and wet, fen-like areas lacking permafrost (Svensson et al., 1999; Johansson et al., 2006; Ström and Christensen, 2007; Bäckstrand et al., 2008). Johansson et al. (2006) reported a significant decline of permafrost and a change of vegetation patterns from hummock vegetation to wet-growing vegetation at the experimental site used in this study during a 30-year period (1970 to 2000). The organic layer at Stordalen mire is between $1 \mathrm{~m}$ and $3 \mathrm{~m}$ deep.

The vegetation is dominated by Eriophorum angustifolium and Carex rostrata in the wet areas, while semi-wet and drier areas, and palsas are dominated by Eriophorum vaginatum, Carex rotrundata and Sphagnum ssp. (Johansson et al., 2006; Bäckstrand et al., 2008). The eddy flux tower location is dominated by wet areas, dry and semi-wet areas were located only in a small sector ranging from the north-western 

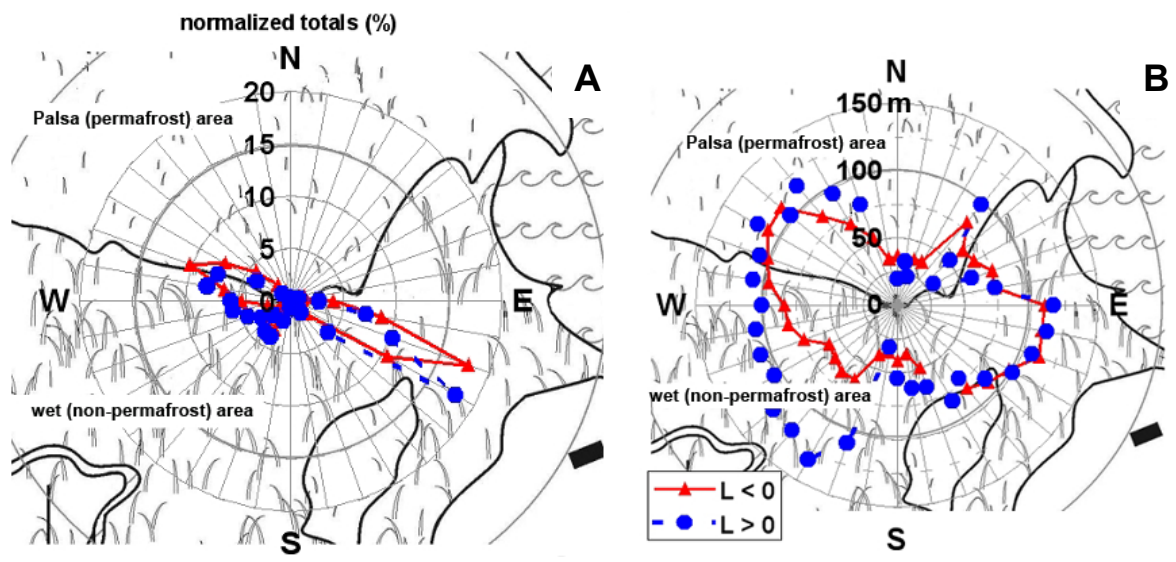

Fig. 1. Frequency distribution (\%) of wind direction (A) and footprint according to Neftel et al. (2008), (B) showing the maximum distance that contributed to the measured fluxes for stable (Monin Obukov length $L>0$, blue dots) and unstable ( $L<0$, red triangles) conditions measured during August and September 2006. The NW to NE-sector of the flux site was dominated by dry permafrost palsas, slightly raised above the surface while most of the fetch was influenced by permanently wet conditions in areas that lacked permafrost.

to the north-eastern direction (Fig. 1; Jackowicz-Korczynski, 2009). In the wet area, Eriophorum angustifolium and Carex rostrata formed a fairly uniform canopy of approximately $0.5 \mathrm{~m}$ height and a leaf area index of about 3.5 (measured in July 2008). The roughness length $\left(z_{0}\right)$, calculated for neutral conditions during the measurement period, was between $0.1 \mathrm{~m}$ and $0.3 \mathrm{~m}$ for $80 \%$ of the data, and for both mean wind directions. At this northern latitude site, the sedges begin to grow early in June, and the canopy is fully developed by July (Ekberg et al., 2009). In 2006, first signs of senescence were observed already at the beginning of August. By the end of the month, large parts of the canopy showed senescence and by mid September, most of the sedges had turned from green to brown colour.

\subsection{Instrumentation and BVOC sampling}

The flux measurement system consisted of a sonic anemometer (USA-1, Metek, Elmshorn, Germany) sampling at $20 \mathrm{~Hz}$ and a Proton Transfer Reaction-Mass Spectrometer (PTRMS, Ionicon, Innsbruck, Austria) for online concentration measurements of a set of BVOCs. The PTR-MS uses soft chemical ionisation methods where compounds in the sample air are protonated by $\mathrm{H}_{3} \mathrm{O}^{+}$-ions in a drift tube for detection by a quadrupole mass spectrometer. The concentrations of different BVOCs were determined by consideration of the primary ion $\mathrm{H}_{3} \mathrm{O}^{+}(\mathrm{m} 21)$, the target $\mathrm{BVOC}$ ion count rate and other instrumental parameters according to Lindinger et al. (1998) and Hayward et al. (2002). It has been shown that this results in an accuracy of $30 \%$ due to instrument and calibration uncertainties (Lindinger et al., 1998; Hayward et al., 2002; Warneke et al., 2003). The PTR-MS has been used for a variety of studies in recent years, including flux measurements of BVOCs above different vegetation types (see reviews by de Gouw and Warneke, 2007; Seco et al., 2007).
Detailed information about the PTR-MS can be found in Lindinger et al. (1998).

The sample air inlet for the BVOC concentration measurements was mounted on an eddy covariance mast on Stordalen mire, directly under the scanning volume of the anemometer at a height of $2.95 \mathrm{~m}$ a.g.l. The sample air passed through a heated PFA tube (inner diameter $8 \mathrm{~mm}$ ) to the PTR-MS that was operated in a small hut, located $12 \mathrm{~m}$ from the flux mast. The air flow from the heated inlet was set to $201 / \mathrm{min}$ and a sub-sample of $0.31 / \mathrm{min}$ was taken from the inlet flow and analysed by the PTR-MS.

The drift tube pressure $\left(p_{\text {drift }}\right)$ of the PTR-MS was kept at $2.2 \mathrm{mbar}$ and the drift tube was heated to $T_{\text {drift }}=60^{\circ} \mathrm{C}$. This led to a kinetic energy of $\mathrm{E} / \mathrm{N}=130$ Townsend (Td) inside the drift tube. During the vegetation period, the PTR-MS was operated with several different measurement sequences scanning for different sets of BVOC components, including Methanol (m33), Acetaldehyde (m45), Acetone (m59) and Isoprene (m69), with typical dwell times of $0.5 \mathrm{~s}$ each. A typical scanning sequence took about $3 \mathrm{~s}$. During measurements, the instrument background was determined regularly by sampling BVOC-free air, which was filtered by a heated catalytic converter (Zero Air Generator, Parker Balston, Haverhill, MA, USA). Readings of the PTR-MS count rate for the different BVOCs were corrected for the mean daily instrument background values normalized to the count rate of the primary ion $\mathrm{m} 21$ during analysis. Based on the standard deviation $(2 \sigma)$ of the background readings and the primary ions, the detection limit of the PTR-MS for the concentration measurements, and thus the signal to noise-ratio $(s / n)$ was calculated. For acetone and methanol the mean $s / n$ was relatively high (18.4 and 9.2, respectively), while mean $s / n$ for acetaldehyde was 3.7. The lowest $s / n$ was found for isoprene, where the measured concentrations exceeded the detection limit only by a factor of 2.2 as a mean 


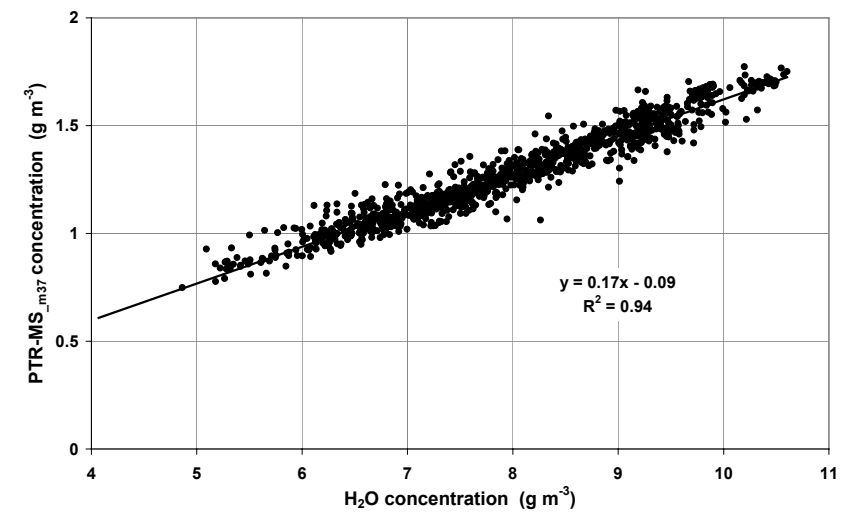

Fig. 2. Comparison of water cluster ion (m37) measurements expressed as $\mathrm{g} \mathrm{m}^{-3}$, calculated from count rates using the standard method (e.g. de Gouw and Warneke, 2007) and instrument calibration, and absolute water vapour concentration measured with a standard temperature and humidity sensor covering the period 1 August to 19 September 2006.

value for the whole measurement period. However, taking only data sampled during August, the mean $s / n$ was slightly higher (2.8) and thus almost comparable with acetaldehyde, while in September, mean $s / n$ for isoprene dropped to only 1.4 due to the low ambient concentration. On some occasions the night-time detection limit exceeded the measured values for isoprene, even in August.

To evaluate the long-term stability of the PTR-MS system, measurements of a water cluster ion (m37) were used. It is formed between the primary ion and water vapour, and can be interpreted to represent ambient water vapour pressure (Ammann et al., 2006; de Gouw and Warneke, 2007). Here, the measured $\mathrm{m} 37$ ion counts were converted into absolute water vapour concentration $\left(\mathrm{g} \mathrm{m}^{-3}\right)$, and compared to the water vapour concentration recorded from a temperature and humidity probe at a resolution of $30 \mathrm{~min}$ mean values. Over the entire sampling period (1 August to 19 September), this comparison showed a stable linear relationship and a high coefficient of determination $\left(R^{2}=0.94\right)$ indicating a good stability of the PTR-MS (Fig. 2).

\subsection{Disjunct eddy covariance technique (DEC)}

The eddy covariance (EC) technique derives fluxes of energy and mass (e.g. sensible heat flux, latent heat flux, $\mathrm{CO}_{2}$ flux) made from measurements of turbulence using a sonic anemometer, and trace gas analysers with a typical time resolution of 50 to $100 \mathrm{~ms}$ (e.g. Aubinet et al., 2000). However, for compounds like BVOCs, the integration time for the analysis of an air sample usually needs to be longer than $100 \mathrm{~ms}$ due to instrument constraints. Due to the low ambient BVOC concentrations expected, integration times of $0.5 \mathrm{~s}$ have been used in this study to reduce the statistical error of the measurements.
The PTR-MS can be used to measure a set of BVOC at a high temporal resolution sequentially, which results in a disjunct time series for the concentration measurements of single BVOCs. For each BVOC included in the measurement sequence, only at $N$ discrete, short time intervals $i$ of length $\tau$ (dwell time) measurements of the BVOC concentration $c$ are available. For this disjunct data set, a synchronized subsample of the continuously available vertical wind data $w$ was used and the resulting flux $F_{c}$ was calculated according to

$F_{c}=\frac{1}{N} \sum_{1}^{N} w^{\prime}(i) \cdot c^{\prime}(i)$,

where $w^{\prime}$ and $c^{\prime}$ are the instantaneous deviations from the mean values of $w$ and $c$ of the sub-sample (Rinne et al., 2001; Karl et al., 2002; Grabmer et al., 2004). Compared to standard EC techniques, this leads to significantly fewer data samples (typically $\sim 20 \%$ of a continuously recorded data set) depending on the number of different BVOCs sampled in a measurement sequence.

Synchronising the PTR-MS and the sonic anemometer data-streams was ensured by connecting the analogue output of the PTR-MS for ion-counts (cps) and mass identifier to the analogue input of the sonic anemometer. This setup prevented time-lags caused by different time signals of the recording system and instruments, and the only lag to be considered hence was caused by air passing through the sampling tube. To synchronize vertical wind and BVOC concentrations, the turbulent fluxes were calculated with varying lag time within the theoretical range estimated from inlet flow and tube dimensions (between 4.0 to $5.0 \mathrm{~s}$ ) with time steps of $0.05 \mathrm{~s}$. The resulting time series was composed from the maximum absolute fluxes obtained for each of the $30 \mathrm{~min}$ intervals separately. For periods where no clear maximum could be identified within the possible range (e.g. at night when fluxes were low) fluxes were calculated with a set lag of $4.50 \mathrm{~s}$. This procedure is comparable to that used by Custer and Schade (2007).

To estimate the error of the flux determination, the standard deviation of the covariance of $w$ and $c$ was calculated using time lags in the region of 1 to $1.5 \mathrm{~s}$ and 7.5 to $8 \mathrm{~s}$ in $0.05 \mathrm{~s}$ intervals, which is far away from the time lag used for flux determination $(\sim 4.5 \mathrm{~s})$ and regarded as a background (Wienhold et al., 1995; Spirig et al., 2005; Brunner et al., 2007). As a mean value, the estimated error in the flux determination $(2 \sigma)$ was found to be $25 \mu \mathrm{g} \mathrm{C} \mathrm{m}^{-2} \mathrm{~h}^{-1}$ for isoprene and $19 \mu \mathrm{g} \mathrm{C} \mathrm{m}^{-2} \mathrm{~h}^{-1}$ for methanol.

All wind data were rotated along the mean flow and the mean vertical wind velocity $(\bar{w})$ was set to zero (block averaging with block length of $30 \mathrm{~min}$ ) (McMillen, 1988). To exclude periods with insufficient turbulence for flux determination, flux data with friction velocity $u_{*}<0.25 \mathrm{~ms}^{-1}$ were omitted during analysis (less than $20 \%$ of the data). As a 
test whether the 30 min averaging period used for calculation of fluxes was adequate and to investigate whether possible low frequency contributions would be neglected, sensible heat fluxes $(H)$ were calculated from $15 \mathrm{~min}, 60 \mathrm{~min}$, and 120 min block averaging for a test period (1 to 9 August 2006), and compared to the standard 30 min block averaging results for $H$. With slopes between 0.98 and 1.00 (and $R^{2}$ between 0.99 and 0.94 ) no significant differences could be found, and it is concluded that a $30 \mathrm{~min}$ averaging period was adequate.

We focus here on the analysis of BVOC measurements taken with a PTR-MS system during a 50 days period (1 August to 19 September 2006) covering the entire second half of a short growing season at the sub-arctic wetland.

\subsection{Isoprene emission algorithm}

Isoprene fluxes are frequently analysed using the algorithms and parameterisations of Guenther et al. $(1993,1997)$ that define emissions by a potential rate under standard conditions $\left(I_{S}\right)$ which varies instantaneously with light in a hyperbolical and with temperature in a modified Arrhenius response:

$I=I_{S} C_{L} C_{T}$

with

$C_{L}=\alpha C_{L 1} \operatorname{PAR}\left(\sqrt{1+\alpha^{2} \mathrm{PAR}^{2}}\right)^{-1}$

$C_{T}=\exp \frac{C_{T 1}\left(T-T_{S}\right)}{\mathrm{RTT}_{S}}\left(1+\exp \frac{C_{T 2}\left(T-T_{M}\right)}{\mathrm{RTT}_{S}}\right)^{-1}$

where PAR ( $\mu \mathrm{mol} \mathrm{m} \mathrm{m}^{-2} \mathrm{~s}^{-1}$ ) is incident quantum flux, $T$ is leaf temperature, $R\left(8.314 \mathrm{JK}^{-1} \mathrm{~mol}^{-1}\right)$ is the universal gas constant, and $T_{M}(314 \mathrm{~K}), \alpha(0.0027), C_{L 1}(1.066), C_{T 1}$ $\left(95000 \mathrm{~J} \mathrm{~mol}^{-1}\right)$ and $\mathrm{C}_{T 2}\left(230000 \mathrm{~J} \mathrm{~mol}^{-1}\right)$ are constants.

We used this approach to analyse and to compare the BVOC flux data measured with this emission algorithm (see Sect. 3.6). However, the generally chosen standard conditions when the light and temperature responses are being unity are for an incident quantum flux of PAR $=1000 \mu \mathrm{mol} \mathrm{m}^{-2} \mathrm{~s}^{-1}$ and a reference leaf temperature $T_{S}$ of $30^{\circ} \mathrm{C}$ but owing to the cool growth environment at our site, we chose here $20^{\circ} \mathrm{C}$ (air) temperature as reference (Ekberg et al., 2009).

\section{Results and Discussion}

\subsection{Main wind direction and source area}

The wind direction frequency distribution showed a bimodal form, with wind frequently either from sections NW or SE under both stable and unstable atmospheric conditions (Fig. 1a). These directions reflect the orientation of the axis of the ca. $10 \mathrm{~km}$ broad valley the site is located in. Under stable conditions, a small contribution from SW directions may possibly be caused by cold drainage flows during night time. The area around the mast within the main wind sector represents a wet section of the mire, dominated by sedges and with the water table mostly above the surface throughout the growing season. The hut which housed the PTR-MS was located $\mathrm{NE}\left(60^{\circ}\right.$ to $\left.80^{\circ}\right)$ from the sonic anemometer, and therefore did not disturb the measurements.

To estimate the source area of the measured turbulent fluxes, footprint calculations were done using a tool presented by Neftel et al. (2008), which is based on the Kormann and Meixner (2001) analytical model. The BVOC fluxes measured at the height of $2.95 \mathrm{~m}$ a.g.l. were dominated by sources located very close to the mast (less than $25 \mathrm{~m}$ distance). On average, the total integrated flux (99\% threshold) was emitted from source areas located at distances less than $150 \mathrm{~m}$ from the measurement system both for stable and unstable conditions (Fig. 1). Thus the fluxes measured were mostly representing the wet mire ecosystem, surrounding birch forest and lake areas were not disturbing the measurements. These results were also confirmed by calculations using the different footprint approaches based on Schuepp et al. (1990) and Wilson and Swaters (1991) (not shown).

For BVOCs like isoprene and methanol the oxidation time under atmospheric conditions is several minutes to hours, much longer than the period of turbulent transport. Kesselmeier and Staudt (1999) and Singh and Li (2007) estimated a lifetime for isoprene of up to $3 \mathrm{~h}$ during daytime depending on ambient $\mathrm{OH}, \mathrm{NO}_{3}$ and $\mathrm{O}_{3}$ concentrations. For methanol, Kesselmeier and Staudt (1999) reported a lifetime of more than a day. The time scale for vertical mixing above the canopy after emission at the surface, $\tau_{\text {mix }}=z / u_{*}$ (Rinne et al. 2007) was less than $10 \mathrm{~s}$ in most cases for the data presented in this study. Rinne et al. (2007) concluded for measurements above a Scots pine forest and based on a transport model with chemical degradation, that isoprene had a lifetime of at least $27 \mathrm{~min}$ during day and about $5 \mathrm{~h}$ during nights while methanol had a lifetime of 2 days. According to their results, the effect of chemical degradation on the fluxes measured was about $10 \%$ for monoterpenes, which have lifetimes comparable to isoprene, and much less for methanol.

\subsection{Turbulent fluxes using DEC}

Two deviations from standard eddy covariance that characterise the DEC technique used in this study may cause underestimation and increased uncertainty of the turbulent BVOC fluxes obtained. First, due to the low concentrations of the trace gases being sampled, PTR-MS integration time (also known as dwell time) for each BVOC of interest must be increased to obtain a tolerable signal to noise ratio $(s / n)$. Typical integration times, which are BVOC dependent, are 0.2 and $0.5 \mathrm{~s}$ (e.g. Schade and Custer, 2004; Spirig et al., 2005; Lee et al., 2005; Brunner et al., 2007), and might cause underestimation of the high frequency part of the turbulence 


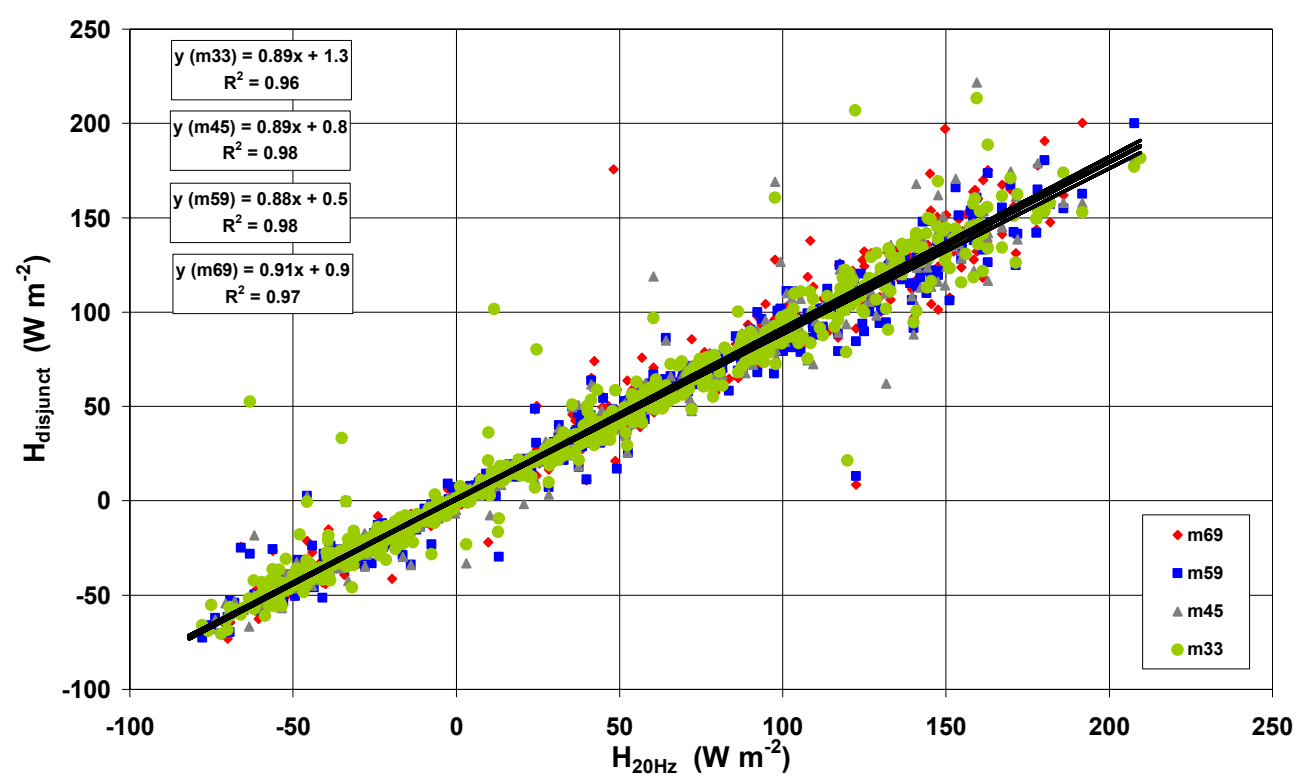

Fig. 3. Comparison of sensible heat flux $H$, calculated from a full $20 \mathrm{~Hz}$ data set $\left(H_{20 \mathrm{~Hz}}\right)$ and for a disjunct sub-sample $\left(H_{\text {disjunct }}\right)$ with $0.5 \mathrm{~s}$ integration time as used for VOC sampling. All available 30 min values from August 2006 with $u^{*}>0.25$ have been used.

spectrum. Second, masses are determined sequentially in the PTR-MS and a number of masses, depending on the BVOCs of interest, are analyzed in a continuously repeating sequence. The time delay between successive measurements of the same BVOC is a function of the number of BVOCs being analysed and the integration time of each. The measurement of the $\mathrm{m} 21$ primary ion at the beginning of each sequence increases this delay further still. The sampling constraints outlined above imply that as the number of BVOCs being measured is increased, the number of samples (and hence sample frequency) taken within each $30 \mathrm{~min}$ flux calculation period is decreased. This may increase the uncertainty of the fluxes obtained.

\subsubsection{Effect of long integration times}

With the DEC set-up used here, turbulent transport in the high frequency domain (i.e., at a rate $>2 \mathrm{~Hz}$ ) is captured incompletely. The proportion of the high frequency losses can be determined by comparing the sensible heat flux calculated using a full $20 \mathrm{~Hz}$ data set of $w^{\prime}$ and $T^{\prime}\left(\mathrm{H}_{20 \mathrm{~Hz}}\right)$, with the sensible heat flux calculated from a disjunct sub-set of the same data set employing a $0.5 \mathrm{~s}$ integration time $\left(H_{\text {disjunct }}\right)$. By this approach the $w^{\prime} T^{\prime}$ subset corresponding to each of the measured compounds used to calculate the BVOC fluxes was taken and compared to the full $20 \mathrm{~Hz} w^{\prime} T^{\prime}$ time series (Fig. 3). The disjunct data set with its $0.5 \mathrm{~s}$ temporal resolution underestimated the turbulent fluxes by approximately $10 \%$ due to missing high frequency regions of the spectrum. The coefficients of determination $\left(R^{2}\right)$ were very high, irrespective of the BVOC.
Spirig et al. (2005) found an underestimation of turbulent fluxes due to neglecting high frequency transport of $10.7 \%$, and Lee et al. (2005) assumed the error for sensible heat flux due to the spectral response to be within $10 \%$. Both had measurement systems placed 5 to $7 \mathrm{~m}$ above forest canopies, with stand heights of 7 and more than $30 \mathrm{~m}$, respectively. In our case, the instruments were about $3 \mathrm{~m}$ above the ground surface (about $2.5 \mathrm{~m}$ above the canopy).

\subsubsection{Effect of reduced sample number}

The sequential sampling of the PTR-MS reduces the number of samples available to calculate the turbulent fluxes significantly compared to a continuous time series of a single mass. Contrary to the spectral loss of the high frequency part of the spectrum, however, this should have no influence on the calculated fluxes as long as the number of samples within the sample period of $30 \mathrm{~min}$ did not fall below a certain minimum. To test this assumption, increasing fractions of the raw data were omitted from a time series of $2 \mathrm{~Hz}$ data, which corresponds to integration times of $0.5 \mathrm{~s}$ used for the BVOCs in this study.

Normalized mean values of $w^{\prime} T^{\prime}$ started to deviate significantly from the value calculated from a full data set once the sub-sample fell below $10 \%$ of the full data series, above this threshold, $w^{\prime} T^{\prime}$ differed not significantly from that obtained with a full data set during most of the day (Fig. 4, upper panel). Below $5 \%$ of the data samples, deviations became much larger and scatter increased notably. Turbulence characteristics, namely $\left(\sigma_{w} / u_{*}\right)$ plotted against atmospheric stability $(z / L)$, followed the general patterns suggested by Panofsky et al. (1977) for unstable conditions $(z / L<0)$ and 

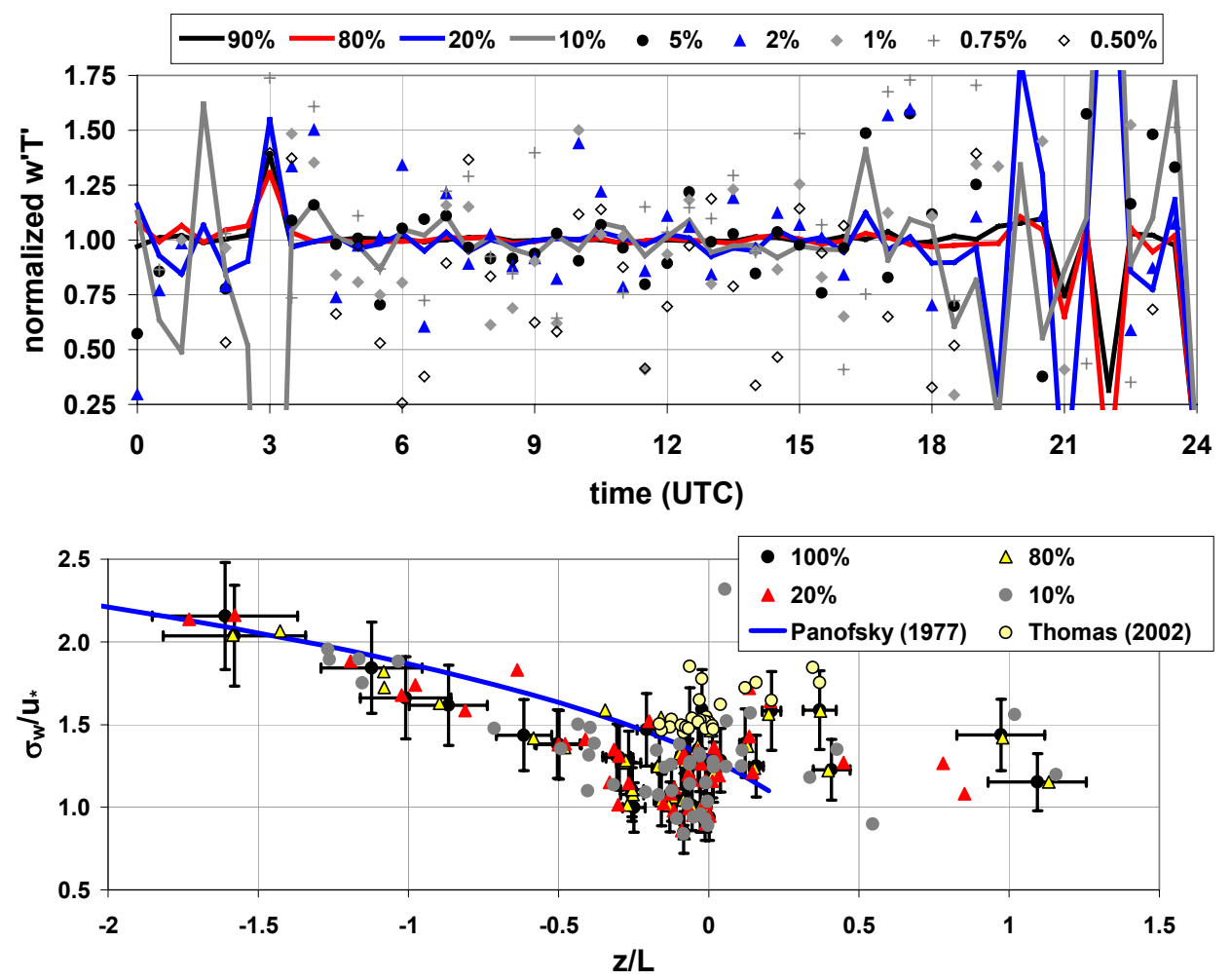

Fig. 4. Comparison of omitting data points for an exemplary day (4 August 2006). Covariances $w^{\prime} T^{\prime}$ calculated from fractions of samples were normalized to the $100 \%$ full set for each $30 \mathrm{~min}$ file (upper panel). Turbulence characteristics $\sigma_{w} / \mathrm{u}_{*}$ against atmospheric stability ( $z / L$, lower panel) agrees well with parameterisations from Panofsky et al. (1977, unstable conditions) and Thomas and Foken (2002, neutral to stable conditions). Error bars for the $100 \%$ data show estimated $15 \%$ uncertainty.

Thomas and Foken (2002) for neutral to stable conditions $(-0.2<z / L<0.4)$ when at least $10 \%$ of the sampled data was used (Fig. 4, lower panel). Overall our analysis indicates that fluxes calculated with less than a fraction of $10 \%$ of a full data set would lead to incorrect results. The effect of reduced sample number on the flux determination has already been theoretically assessed by Lenschow et al. (1994). We applied their theoretical results to the data and experimental set-up of this study for a test period (1 to 9 August 2006) and found a theoretical flux error variance of less than $5 \%$ in most cases, while only single values exceeded error variances of $10 \%$ of the flux, supporting the conclusion that the flux error caused by the disjunct data set is negligible for the set-up used in this study. Similarly, Grabmer et al. (2004) found that the reduction of the samples had virtually no influence on the flux measurement in their study above a Norway spruce forest, and Karl et al. (2002) reported an error based on the disjunct sampling scheme of about $1 \%$ of the flux for time scales very similar to our setup. In our experimental set-up, due to the sequential sampling of the BVOC concentrations, a sub-sample of about $16 \%$ of the full data set was used. Since the overall flux loss and precision of the measurements depends on averaging time and sampling interval, measurements were restricted to not more than six masses.

\subsubsection{Tube damping effects}

For variations in BVOC concentrations, damping in the inlet line might occur depending on tube dimensions and flow rate (e.g. Lenschow and Raupach, 1991). Although this would reduce the measured fluxes, this effect is considered to be of minor importance compared to spectral losses caused by low sampling frequency (Karl et al., 2002; Spirig et al., 2005; Custer and Schade, 2007). An estimate for the flux loss caused by mixing in the tube based on typical values of the instrumental set-up for this study is less than 5\% when applying theoretical transfer functions (Lenschow and Raupach, 1991).

However, measured BVOC constituents might also stick to the walls of the inlet system resulting in an underestimation of fluxes. For example, methanol is known to interact with metal surfaces (de Gouw and Warneke, 2007). As the damping depends strongly on the individual instrumental set-up (measurement height, tube dimensions, flow rate as well as wind speed), comparisons with literature are difficult. Nevertheless, Brunner et al. (2007) reported a loss of turbulent exchange due to sorption effects to the wall of the inlet system of $25 \%$ to $55 \%$ for methanol, depending on wind speed, stating that this effect would be more important 
than other damping effects. Applying Ogive spectral analysis, Ammann et al. (2006) found high damping for fluxes of the water cluster ion $\mathrm{m} 37$, which can be used as a proxy for water vapour pressure. Ogives can be used to estimate damping effects for measured compounds, for instance compared to the un-dampened sonic temperature measurements, since they describe the cumulative contribution of different frequency ranges to the total turbulent flux. However, as a spectrum can only be calculated from equidistant time series, this technique could not be used with the disjunct data set in our study to estimate damping effects at integration times lower than $\sim 3 \mathrm{~s}$ (duration of the scanning sequence). To minimize damping and losses due to sorption effects and to prevent condensation, the inlet line was heated and kept well above ambient temperature in our instrument set-up.

\subsection{Meteorological conditions}

The study period was characterized by prevailing high pressure conditions and relatively high irradiance during most of the month of August. Only a few overcast days were encountered in August, for instance, on 7-9 August (Fig. 5b). In September, the weather pattern was more unsettled with frequent cloudy periods. Daily air temperature maxima exceeded $20^{\circ} \mathrm{C}$ at the beginning of the measurement period ( 2 and 3 August), and $17^{\circ} \mathrm{C}$ on days with high irradiance towards the end of the month. Minimum air temperatures close to $2{ }^{\circ} \mathrm{C}$ were observed frequently towards the end of August, with first frost occurring $\left(-0.8^{\circ} \mathrm{C}\right)$ on 20 August. During September, air temperature mostly ranged from about $5^{\circ} \mathrm{C}$ to $12{ }^{\circ} \mathrm{C}$ and lacked strong diel variation (Fig. 5a).

\subsection{BVOC fluxes}

\subsubsection{Seasonal and diurnal flux variation}

A clear diel pattern for fluxes of isoprene was visible until early September and for methanol during the beginning of August (Fig. 5c, d), whereas no clear diel flux pattern for acetaldehyde and acetone emerged (not shown). The high ambient temperature and high levels of photosynthetically active radiation PAR in early August promoted significant daytime emission of isoprene up to $1385 \mu \mathrm{g} \mathrm{C} \mathrm{m}{ }^{-2} \mathrm{~h}^{-1}\left(1571 \mu \mathrm{g} \mathrm{m}^{-2} \mathrm{~h}^{-1}\right)$, while on the following days, isoprene emissions were typically between 400 and $500 \mu \mathrm{C} \mathrm{m}^{-2} \mathrm{~h}^{-1}$. At night the measured fluxes for isoprene were close to zero as must be expected from the lightdependent foliar production of isoprene and the absence of plant storage for this particular BVOC. In contrast to relatively high emissions during the first half of August, fluxes at the end of the month were less than $250 \mu \mathrm{g} \mathrm{C} \mathrm{m}^{-2} \mathrm{~h}^{-1}$ even during favourable weather conditions. Vegetation at this time of year showed already clear signs of senescence, that were rapidly accelerated after the frost observed on 20 August $\left(T_{a}=-0.8^{\circ} \mathrm{C}\right)$ and by overall low daily minimum air temper- ature around $2^{\circ} \mathrm{C}$. It is likely that air temperature at the actual height of vegetation (ca. $0.5 \mathrm{~m}$ ) was well below these values that were measured at the eddy tower at a height of $2.5 \mathrm{~m}$. Ekberg et al. (2009) could not detect any isoprene emissions from the sedge leaves during a September campaign, similar to the observations at ecosystem scale.

In a boreal fen in southern Finland, Haapanala et al. (2006) reported isoprene fluxes varying from 0 to $400 \mu \mathrm{g} \mathrm{m}^{-2} \mathrm{~h}^{-1}$ measured by relaxed eddy accumulation on a number of days during 2004 (July to October) and 2005 (April to July). Maxima at that site were measured in June and July. A number of other BVOC flux studies in northern wetland ecosystems were conducted with chamber methods (Janson et al., 1999; Hellén et al., 2006; Tiiva et al., 2007a, b) and with reported standardized $\left(1000 \mu \mathrm{mol} \mathrm{m} \mathrm{m}^{-2} \mathrm{~h}^{-1}, 30^{\circ} \mathrm{C}\right)$ isoprene fluxes ranging from 70 to $8960 \mu \mathrm{g} \mathrm{m}^{-2} \mathrm{~h}^{-1}$, measured at ambient conditions and with elevated UV and Ozone levels. The isoprene fluxes presented here confirm an emerging picture whereby emission rates from northern wetlands can be comparable or higher to those observed in boreal forest ecosystems. Janson et al. (1999) stated that a Sphagnum fen emitted isoprene fully comparable to a boreal spruce forest, and Tiiva et al. (2007a) concluded from their studies that isoprene emissions from boreal peatlands are of the same magnitude as observed from boreal spruce forests. For sub-arctic peatlands, they found even higher emission rates than reported for forests, especially under warm conditions during summer (Tiiva et al., 2007b). Rinne et al. (2000) observed mean day-time isoprene emissions of $\sim 14.4 \mu \mathrm{g} \mathrm{m}^{-2} \mathrm{~h}^{-1}\left(\sim 12.7 \mu \mathrm{g} \mathrm{m}^{-2} \mathrm{~h}^{-1}\right)$ for a boreal mixed forest in northern Finland, which is less than the mean emission rate for the Stordalen site for the whole measuring period presented in this study. However, during the Boreal Ecosystem-Atmosphere Study (BOREAS) normalized $\left(20^{\circ} \mathrm{C}, 1000 \mu \mathrm{mol} \mathrm{m}^{-2} \mathrm{~s}^{-1}\right)$ isoprene emission rates between ca. 600 and $3130 \mu \mathrm{g} \mathrm{C} \mathrm{m}{ }^{-2} \mathrm{~h}^{-1}$ were measured for boreal spruce and aspen forests in Canada during campaigns (spring, summer, late summer) (Fuentes et al., 1999; Westberg et al., 2000). These emission rates exceeded those found for the sub-arctic wetland presented in our study.

For methanol, daytime emissions up to $100 \mu \mathrm{g} \mathrm{C} \mathrm{m}^{-2} \mathrm{~h}^{-1}$ (268 $\mu \mathrm{g} \mathrm{m}^{-2} \mathrm{~h}^{-1}$ ) were observed in the beginning of $\mathrm{Au}-$ gust (Fig. 5d). However, from the end of the month onwards fluxes rapidly dropped to values close to the detection limit. Reports on methanol emissions are scarce but our data appear to be within the range of methanol fluxes observed in temperate ecosystems. For grassland, ryegrass and bare soil in central Europe, for instance, Brunner et al. (2007), Custer and Schade (2007) and Schade and Custer (2004) observed fluxes of $\sim 100 \mu \mathrm{g} \mathrm{m}^{-2} \mathrm{~h}^{-1}$ to $\sim 500 \mu \mathrm{g} \mathrm{m}^{-2} \mathrm{~h}^{-1}$ $\left(\sim 38 \mu \mathrm{g} \mathrm{C} \mathrm{m}^{-2} \mathrm{~h}^{-1}\right.$ to $\left.\sim 188 \mu \mathrm{g} \mathrm{C} \mathrm{m}{ }^{-2} \mathrm{~h}^{-1}\right)$, respectively.

The rapid changes in fluxes of isoprene and methanol towards the end of the observation period in autumn can be visualised by comparing mean diel courses from the beginning of August to mid-September. Figure 6 summarises four 

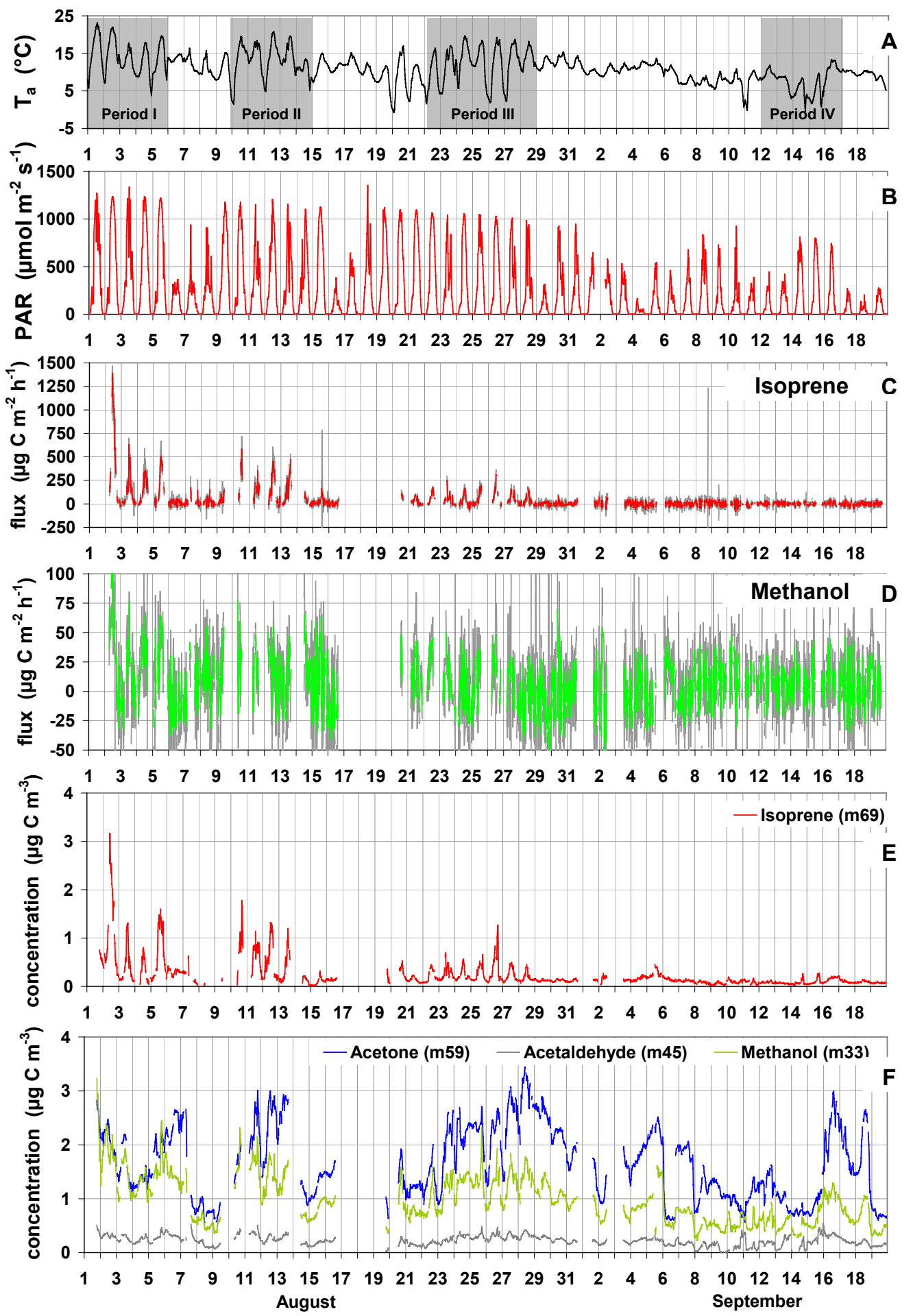

Fig. 5. Ambient air temperature $T_{a}$ (panel A), photosynthetically active radiation PAR (panel B), ecosystem exchange of isoprene and methanol (C, D; grey shading indicates fluxes \pm 2 standard deviations of the background signal of the fluxes), and concentrations of isoprene, methanol, acetone and acetaldehyde (E, F) measured by a Proton Transfer Reaction mass spectrometer (PTR-MS) at a height of $2.95 \mathrm{~m}$ at the Stordalen mire field site (sub-arctic Sweden) during August and September 2006 (1 August to 19 September 2006). Specific periods (I-IV) mentioned in the text are indicated in panel A. 

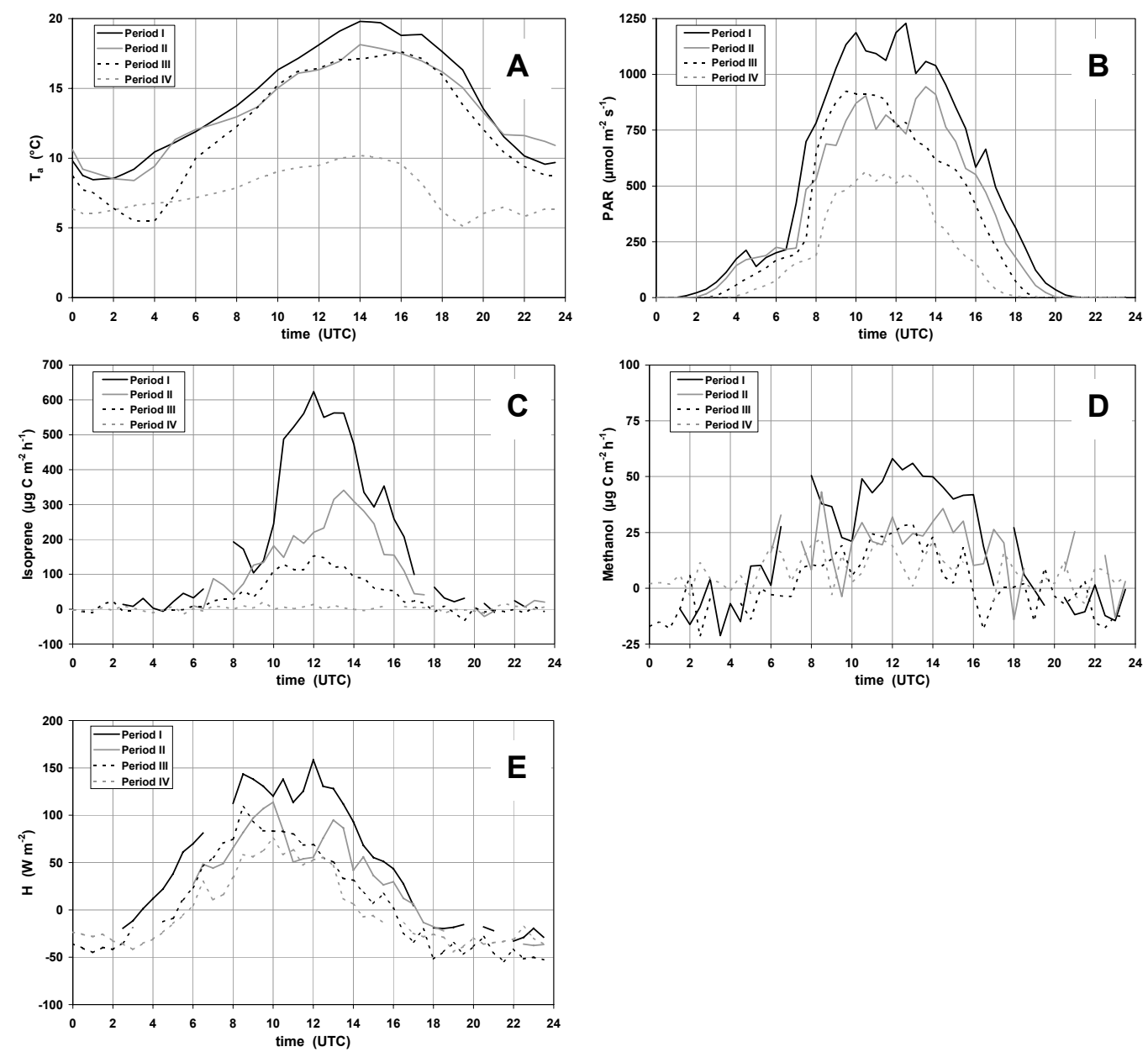

Fig. 6. Mean diel courses for ambient air temperature $T_{a}$, photosynthetically active radiation PAR, and turbulent fluxes of sensible heat $\mathrm{H}$, isoprene and methanol for different periods (period I: 1/8-5/8; II: 10/8-14/8; III: 22/8-28/8, and IV: 12/9-16/9) during 2006.

periods that covered 1 to 5 August (Period I), 10 to $14 \mathrm{Au}$ gust (Period II), 22 to 28 August (Period III), and 12 to 16 September (Period IV). Days were becoming visibly shorter towards the end of the period but all selected days were fairly sunny (Fig. 6b) and characterised by relatively similar maximum temperatures (except for Period IV, Fig. 6a). Emissions of isoprene during Period III reached only about $50 \%$ of those measured during Period I or II at similar levels of PAR and $\mathrm{T}$ and had ceased during Period IV (by mid-September; Fig. $6 c, 7 a, b)$, reflecting the well known decline of isoprene emissions in senescing leaves. Standardised canopy isoprene emission potentials, when calculated following Guenther et al. (1995; see also section 3.6) were 538, 318 and $163 \mu \mathrm{g} \mathrm{C} \mathrm{m}^{-2} \mathrm{~h}^{-1}$ for periods I-III, respectively, with $R^{2}$ of the fit declining from 0.67 to 0.5 . They could not be obtained for period IV when fluxes were close to zero.

Morning methanol fluxes peaked notably earlier compared to isoprene (Fig. 6d), saturating at levels of PAR $>750 \mu \mathrm{mol} \mathrm{m}^{-2} \mathrm{~s}^{-1}$ (Fig. 7b). Methanol is stored internally which explains the strong release just after starting stomatal activity in the morning (e.g. Nemecek-Marshall et al., 1995; Niinemets et al., 2004; Seco et al., 2007). Interestingly, the strong seasonal decline visible in peak isoprene rates was not as pronounced for methanol (Figs. 6d, 7a, b). Methanol production is known to be affected by vegetation growth (e.g. Nemecek-Marshall et al., 1995; Niinemets et al., 2004; Hüve et al., 2007), but is also emitted from decaying vegetation (e.g. Nemecek-Marshall et al., 1995; Karl et al., 2001; Seco et al., 2007). Over the course of a season these two processes may compensate each other to some degree resulting in an overall lower seasonal variation.

The seasonality of BVOC emissions has only been addressed in a few studies so far. Pressley et al. (2005) reported a gradual increase of isoprene emissions during spring, a significant variation of emissions dependent on light and temperature regimes during summer, and a gradual decline in isoprene emissions in late summer observed during a longterm study in a mixed hardwood forest. Similarly, Westberg et al. (2000) and Fuentes et al. (1999) found a seasonality in the isoprene emission rates for different boreal forest species 

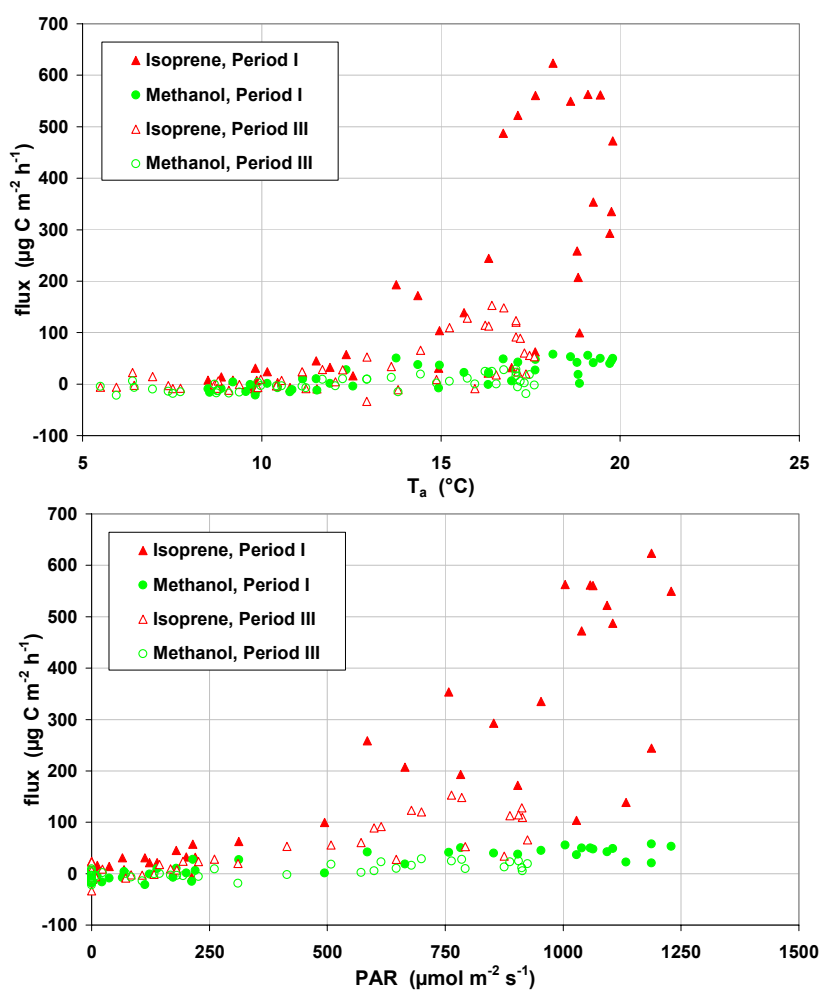

Fig. 7. Mean diel courses of fluxes of isoprene and methanol in relation to ambient temperature $T_{a}$ (upper panel) and photosynthetically active radiation PAR (lower panel) for two contrasting periods (I: 1/8-5/8; III: 22/8-28/8) during the field season 2006.

(black spruce, aspen) during field campaigns at the BOREAS sites, and Fuentes et al. (1999) concluded, that in addition to the seasonality the isoprene emissions of the boreal aspen forest have been strongly reduced by low temperatures $\left(<10^{\circ} \mathrm{C}\right)$.

\subsubsection{Dependence on environmental parameters}

Overall, the ecosystem isoprene flux showed the expected increase with increasing temperature and PAR (i.e. Guenther, 1997; Kesselmeier and Staudt, 1999; Seco et al., 2007), with the response to air temperature being extremely steep at air temperatures above ca. $15^{\circ} \mathrm{C}$. At a temperature below this value emissions were close to zero, regardless of incoming PAR (Fig. 8a). Isoprene flux maxima tended to coincide with maxima of PAR (Fig. 6b, c) which is also visible as a strong hysteresis in the isoprene-temperature relationship (Fig. 7a). In August, the morning onset of isoprene emission lagged PAR by about $2 \mathrm{~h}$, with fluxes being measurable once PAR exceeded $500 \mu \mathrm{mol} \mathrm{m}^{-2} \mathrm{~s}^{-1}$ (Fig. 6b, c). Overall, the increase of canopy isoprene emissions with PAR was notably more linear compared to the typically observed strong hyperbolic saturation at high-light levels. However, maximum rates of PAR at the study site hardly exceeded
$1200 \mu \mathrm{mol} \mathrm{m} \mathrm{m}^{-2} \mathrm{~s}^{-1}$ and it seems unlikely that isoprene production on canopy scale was light saturated for long period, if at all.

Although maximum fluxes of methanol occurred during periods of warm temperatures $\left(>20^{\circ} \mathrm{C}\right)$ and high levels of PAR $\left(>750 \mu \mathrm{mol} \mathrm{m}{ }^{-2} \mathrm{~s}^{-1}\right)$, the correlation with these variables was weak (Fig. 8b). For a grassland in central Europe, Brunner et al. (2007) found a much clearer relation of methanol emission to $T_{a}$ and PAR; in their study, emissions varied also with assimilation rates. Custer and Schade (2007) reported a temperature-response for methanol fluxes for ryegrass, and in both studies methanol emissions were modelled based on these relationships and leaf area index at the study site. Unlike isoprene, emission of methanol is affected by stomatal opening. It remains to be tested whether at our flux site surface- or canopy conductance, or canopy assimilation rate can aid to explain short-term variation of methanol emissions (Nemecek-Marshall et al., 1995; Niinemets et al., 2004; Hüve et al., 2007), or (in the case of assimilation rate) those of isoprene. These data are available from eddy flux measurements of $\mathrm{CO}_{2}$ and water vapour (Jackowicz-Korczynski, 2009) and will be presented in a future analysis (Holst et al., in preparation). While night-time fluxes of isoprene were virtually zero, fluxes of methanol at night reached ca. $-30 \mu \mathrm{g} \mathrm{C} \mathrm{m}{ }^{-2} \mathrm{~h}^{-1}$ (Figs. $6 \mathrm{~d}, 8 \mathrm{~b}$ ), thus indicating a flux directed to the surface. As methanol is water soluble, one could speculate that condensation and deposition on dew-wetted surfaces or water patches at the wetland site could, besides oxidation processes, explain this behaviour (Seco et al., 2007). This observation affects not only the diel flux pattern, but also complicates, for example, measurements of water soluble substances with chamber studies (Janson et al., 1999).

A linear relationship to the sensible heat flux, that seems to be typical for isoprene fluxes (Pressley et al., 2005, 2006) did also emerge for methanol (Fig. 9). In both cases, the relationship varied seasonally, with the effects of decaying vegetation visible as a strongly decreasing slope, especially in case of isoprene (Fig. 9). The fact that both isoprene and methanol increase linearly with $H$ is at first perhaps surprising since the relationship with weather variables like temperature differed distinctly for these two compounds. However, given its dependency on the available energy (e.g. shortwave radiation fluxes) and temperature differences, $H$ seems to reflect well the temperature and light conditions associated with the emission of isoprene and methanol, although the diurnal cycle of $\mathrm{H}$ and temperature is dissimilar with maximum temperatures normally reached in the afternoon, when $H$ is already past its daytime peak rates. The variation in the slope of the correlation of $H$ and emission, however likely reflects variation in the BVOC production rates. Since measurements of sensible heat fluxes are much more easy to conduct on an annual basis these kind of empirical linear relationships could be used for gap filling of BVOC time series, at least over short periods (hours to days) if the sensible heat-and 

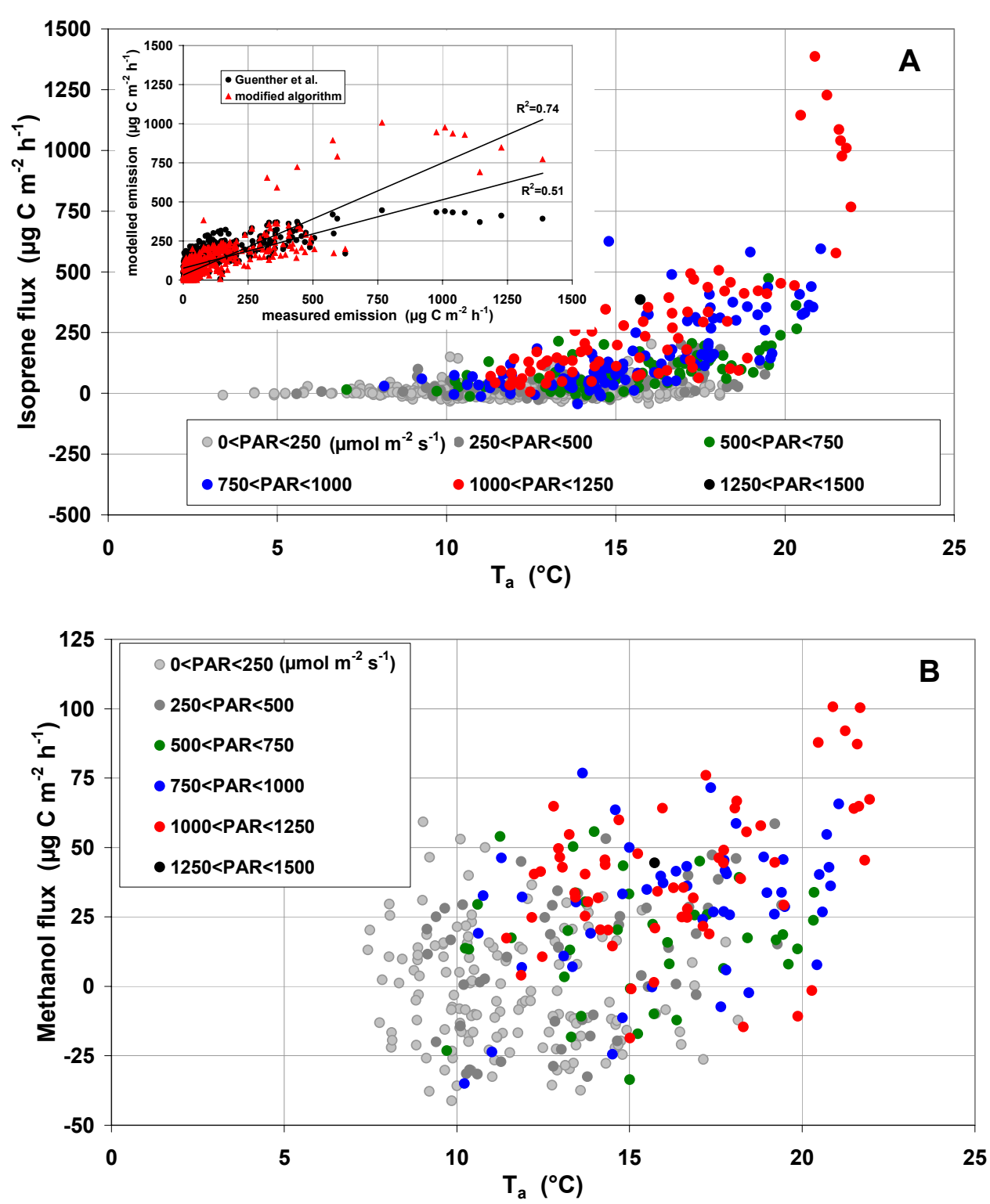

Fig. 8. Measured fluxes of isoprene (panel A; 1-31 August 2006) and methanol (panel B; 1-16 August 2006) related to ambient air temperature $T_{a}$ and ambient level of photosynthetically active radiation (PAR, colour coded). The inset in panel A shows emission modelled with two different approaches from a non-linear curve fit against the measured data. Black symbols denote results using the standard Guenther et al. (1993) algorithm, red symbols show fitted data with $I_{s 20}$ varying additionally in response to average temperature over the last $48 \mathrm{~h}$.

BVOC flux data is sufficient to represent the seasonal variation that obviously exist in the slope of the relationship. In absence of more complex model analyses this would allow a simple means of extrapolating from seasonal BVOC flux measurement campaigns to growing-season budgets.

\subsection{BVOC concentrations}

The concentrations of several masses (corresponding to isoprene, acetaldehyde, acetone and methanol) are presented in Fig. 5e and f, and Fig. 10 for the same periods as in Fig. 6. A clear diel pattern was observed until early September for isoprene and methanol with maxima typically reached during daytime (Fig. 10). For acetone and acetaldehyde concentrations did not vary in similarly clear diel pattern but lower frequency fluctuations were observed with concentrations increasing and decreasing over periods of few days.

Concentrations of isoprene and methanol were highest at high levels of irradiance $\left(>1 \mu \mathrm{g} \mathrm{C} \mathrm{m}^{-3}(0.38 \mathrm{ppb})\right.$ for isoprene and $1.5 \mu \mathrm{g} \mathrm{C} \mathrm{m}^{-3}$ (2.8 ppb) for methanol). A maximum concentration of isoprene of $3.2 \mu \mathrm{g} \mathrm{C} \mathrm{m}^{-3}$ (1.2 ppb) was observed on a comparably hot (maximum temperature of $23.2^{\circ} \mathrm{C}$ ) and sunny day (2 August), when also fluxes were 


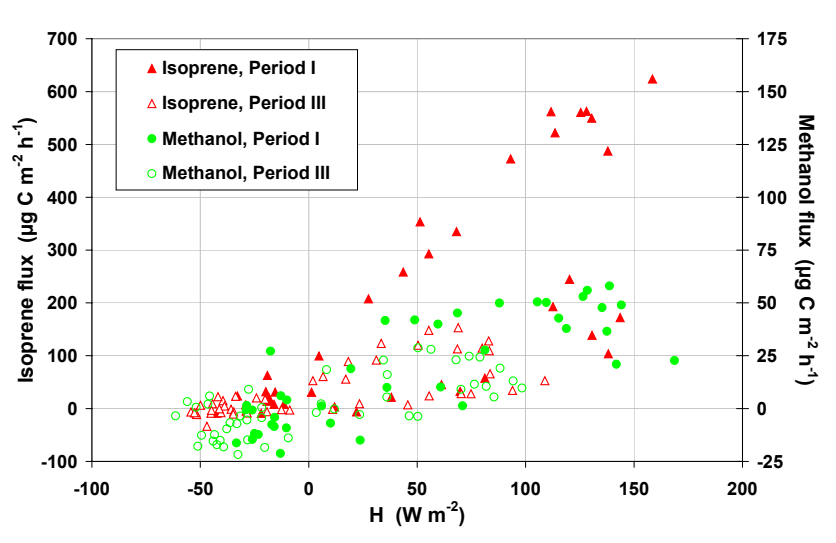

Fig. 9. Mean diel courses of fluxes of isoprene and methanol in relation to mean sensible heat flux $H$ for two contrasting periods (I: 1/8-5/8; III: 22/8-28/8) during the 2006 field season.
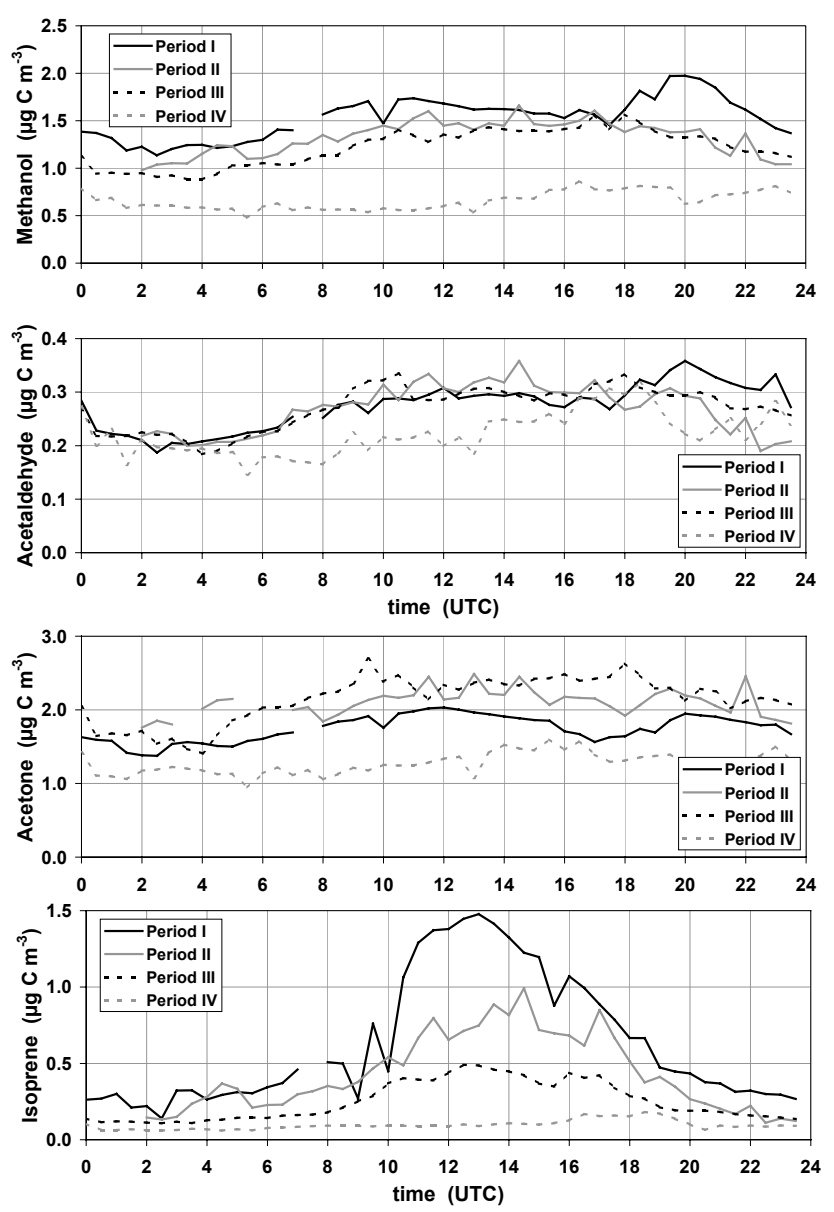

Fig. 10. Mean diel courses of methanol, acetaldehyde, acetone and isoprene concentrations for four different periods (period I: $1 / 8-5 / 8$; II: 10/8-14/8; III: 22/8-28/8, and IV: 12/9-16/9) measured above Stordalen mire in sub-arctic Sweden in 2006. highest. Peak concentrations during the rest of the month were about $1 \mu \mathrm{g} \mathrm{C} \mathrm{m}^{-3}$, and rarely exceeded $0.3 \mu \mathrm{g} \mathrm{C} \mathrm{m}^{-3}$ on cloudy days. Expressed on a carbon basis, concentration maxima for methanol were similar or higher than isoprene, they reached $3.2 \mu \mathrm{g} \mathrm{C} \mathrm{m}^{-3}$ (6.0 ppb, 1 August), and daily maxima were in the range of 1.5 to $2.3 \mu \mathrm{g} \mathrm{C} \mathrm{m}^{-3}$ on most other days during the observation period. For other BVOCs, concentration peaks of $3.4 \mu \mathrm{g} \mathrm{C} \mathrm{m}^{-3}$ (acetone, 28 August) and $0.5 \mu \mathrm{g} \mathrm{C} \mathrm{m}^{-3}$ (acetaldehyde, 16 September) were observed with means for acetone and acetaldehyde being $1.7 \mu \mathrm{g} \mathrm{C} \mathrm{m}^{-3}$ (1.0 ppb) and $0.2 \mu \mathrm{g} \mathrm{C} \mathrm{m}^{-3}(0.2 \mathrm{ppb})$, respectively. Isoprene concentrations dropped close to zero at night, when fluxes also approached zero. While concentrations of methanol showed a first peak already about $3 \mathrm{~h}$ earlier compared to isoprene, a second maximum occurred on some days in the evening at sunset (Fig. 10), most likely caused by decreasing mixing layer heights. The concentration of methanol remained at values well above $>0.8 \mu \mathrm{g} \mathrm{C} \mathrm{m}^{-3}(1.5 \mathrm{ppb})$ during nights with a clear trend of concentration minima declining towards the autumn. In contrast to these diel patterns Rinne et al. (2005) reported concentrations of both isoprene and methanol to peak late in the evening possibly related to high irradiance at the time of measurement (July) at their northern-latitude site. Furthermore, boundary-layer dynamics, i.e. decreasing or increasing mixing-layer heights, might cause rising of BVOC concentrations during night-time and dilution of concentrations during day-time. On the other hand, reduced or missing emissions during night together with short chemical life-time (i.e. isoprene) might outnumber effects resulting from decreasing mixing-layer heights.

The standardised canopy BVOC fluxes at our site were comparable, or higher, than those at more southern locations (Sect. 3.4), but peaks in emission rates were observed rarely because of the overall low light levels and cool growing season temperatures. Since fluxes strongly influence atmospheric concentrations, these environmental constraints contributed to concentrations being thus somewhat lower compared to observations in tropical and mid-latitude ecosystems (e.g. Karl et al., 2004, 2005; Custer and Schade, 2007; Brunner et al., 2007), especially for isoprene and acetaldehyde. While the maximum concentrations at Stordalen mire were up to $1.2 \mathrm{ppb}$ (isoprene), 6.0 ppb (methanol), $2.1 \mathrm{ppb}$ (acetone) and $0.5 \mathrm{ppb}$ (acetaldehyde), Karl et al. (2004) reported maximum concentrations of ca. $5 \mathrm{ppb}$ (isoprene), ca. $7 \mathrm{ppb}$ (methanol), ca. $2.8 \mathrm{ppb}$ (acetone) and ca. 1.6 ppb (acetaldehyde) measured above a tropical rain-forest, and similar concentrations above a temperate Loblolly Pine plantation (Karl et al., 2005). The atmospheric concentrations at our sub-arctic wetland study site are comparable to values presented for the canopy layer of a boreal mixed forest in southwest Finland measured in July (Rinne et al., 2005), where concentrations between ca. 4 and $6 \mathrm{ppb}$ for methanol, 0.7 to $2 \mathrm{ppb}$ for acetaldehyde, and around $0.5 \mathrm{ppb}$ for isoprene had been recorded. Haapanala et al. (2006) measured isoprene 
concentrations of approximately $0.8 \mathrm{ppb}$ above a boreal fen in southern Finland.

\subsection{Do the fluxes at our northern site follow the stan- dard temperature and light response?}

To assess whether the emissions of isoprene at this northern site follow the algorithms and parameterisations of Guenther et al. (1993, 1997; see Sect. 2.4), the flux data were used to determine $I_{S}$ by non-linear curve-fitting (Sigma Plot 9.0, Systat Software Inc.), comparing three cases:

(a) Using the standard values for the coefficients in the temperature and light response functions as presented in Guenther (1997) (with the temperature response being unity at a reference temperature of $20^{\circ} \mathrm{C}$ );

(b) Allowing $I_{S}$ to vary with average air temperature of the past $48 \mathrm{~h}\left(T_{48}\right)$ as found at Stordalen mire for the leaf isoprene emission of Eriophorum and Carex (Ekberg et al., 2009), best described by the dimensionless multiplier $m=$ $a \exp \left(b T_{48}\right)$ with $T_{48}$ in ${ }^{\circ} \mathrm{C}$ and $b$ in ${ }^{\circ} \mathrm{C}^{-1}$;

(c) Modifying the instantaneous temperature response of $I$, in particular the coefficient CT1 (standard value: $95000 \mathrm{~J}$ mol $^{-1}$; Guenther et al., 1995).

Agreement between measured data and calculated values was in all cases fairly good, with poorest $\left(R^{2}=0.51\right)$ for the Guenther et al. (1993) algorithms with the standard setting (Fig. 8a, inlet). In that case, $I_{s}$ derived from the nonlinear curve-fitting was $329 \mu \mathrm{g} \mathrm{m}^{-2} \mathrm{~h}^{-1}$ (Table 1). The best agreement between measured and calculated isoprene flux $\left(R^{2}=0.74\right)$ was achieved when the emission potential $I_{s}$ was varied with a dimensionless multiplier including $T_{48}$ at otherwise standard instantaneous temperature response, with $I_{s}=246 \mu \mathrm{g} \mathrm{C} \mathrm{m}{ }^{-2} \mathrm{~h}^{-1}$. Values obtained for parameters $a$ and $b$ in the simple exponential function were 0.18 and 0.14 , respectively. When coefficient CT1 of the temperature response was allowed to vary, the $R^{2}$ for measured vs. fitted data was more or less similar to the $T_{48}$ case but CT1 was much larger $\left(225000 \mathrm{~J} \mathrm{~mol}^{-1}\right)$ than the original value $\left(95000 \mathrm{~J} \mathrm{~mol}^{-1}\right)$. Table 1 provides a brief summary over these results, including a re-expression of the values obtained for $I_{S}$ to $30^{\circ} \mathrm{C}$ which is the standard temperature often used in the literature.

The estimate for $I_{S}$ (at $20^{\circ} \mathrm{C}$ ) obtained using the Guenther et al. algorithm of $329 \mu \mathrm{g} \mathrm{C} \mathrm{m}{ }^{-2} \mathrm{~h}^{-1}$ lies within the large range of values reported in other studies (that used $30^{\circ} \mathrm{C}$ as reference temperature) in boreal fen ecosystems when expressing these for $20^{\circ} \mathrm{C}$. For example, Janson et al. (1999) found maximum emission rates of $408 \mu \mathrm{g} \mathrm{C} \mathrm{m}^{-2} \mathrm{~h}^{-1}$ (at $30^{\circ} \mathrm{C}$ and $1000 \mu \mathrm{mol} \mathrm{m}^{-2} \mathrm{~s}^{-1}$ ) for a Sphagnum fen in Sweden, while Haapanala et al. (2006) reported up to $600 \mu \mathrm{g} \mathrm{C} \mathrm{m}{ }^{-2} \mathrm{~h}^{-1}$ (680 $\mu \mathrm{g}$ isoprene $\mathrm{m}^{-2} \mathrm{~h}^{-1}$ ) for a site in Finland. Hellén et al. (2006) noticed a lower mean isoprene emission potential of $197 \mu \mathrm{g} \mathrm{C} \mathrm{m}{ }^{-2} \mathrm{~h}^{-1}\left(224 \mu \mathrm{g} \mathrm{m}^{-2} \mathrm{~h}^{-1}\right)$ in their study. Tiiva et al. (2007a, b) measured mean standardised emissions varying from $70 \mu \mathrm{g}$ isoprene $\mathrm{m}^{-2} \mathrm{~h}^{-1}$ to more
Table 1. Comparison of standard isoprene emission rates (in $\mu \mathrm{g} \mathrm{C} \mathrm{m}$ ground $\mathrm{h}^{-1}$ ) obtained by three slightly modified algorithms and for two different standard temperatures $\left(20^{\circ} \mathrm{C}\right.$ and $\left.30^{\circ} \mathrm{C}\right)$.

\begin{tabular}{lll}
\hline & $I_{S-20}$ & $I_{S-30}$ \\
\hline Guenther et al. (1993), standard & 329 & 1148 \\
Guenther et al. (1993), modified CT1 & 458 & 9292 \\
Guenther et al. (1993) \& $T_{48}$ & 246 & 907 \\
\hline
\end{tabular}

than $8900 \mu \mathrm{g} \mathrm{m}^{-2} \mathrm{~h}^{-1}$ in microcosms filled with a range of wetland plants and mosses in experiments with ambient conditions tested against elevated UV and Ozone levels. When expressed to be unity at $20^{\circ} \mathrm{C}$, these standardised rates range from 17 to $2200 \mu \mathrm{g} \mathrm{C} \mathrm{m}{ }^{-2} \mathrm{~h}^{-1}$. As a mean value for ambient conditions during the growing season, they reported emission rates (normalized to $30^{\circ} \mathrm{C}$ ) of $894 \mu \mathrm{g} \mathrm{C} \mathrm{m}^{-2} \mathrm{~h}^{-1}$ (246 $\mu \mathrm{g} \mathrm{C} \mathrm{m}^{-2} \mathrm{~h}^{-1}$ at $20^{\circ} \mathrm{C}$, Tiiva et al., 2007a).

When fitting models to field observations a differentiation between correlation and causation is often difficult. A very high temperature sensitivity of isoprene fluxes as indicated by the high values of CT1 is clearly visible in our data (e.g., in Fig. 8), but yields extraordinarily large values of $I_{S}$ when expressed at the commonly used temperature of $30^{\circ} \mathrm{C}$ (Table 1), rather than the $20^{\circ} \mathrm{C}$ base we suggest as the more appropriate value. Such a strong temperature response could be interpreted as an acclimation of the vegetation to growth in the cold environment, but highlights at the same time the problems arising when uncritically adopting standard temperatures that are clearly outside a region's typically observed weather conditions. By accounting for short-term temperature-history in the above simple model, the typical standard conditions to obtain $I_{s}$ (instantaneous light and temperature) are expanded by an added constraint which can be interpreted as variation in the leaf enzymatic capacity in response to a changing environment. As measurements of BVOC emissions increasingly move from few day campaigns to capture the seasonal variation this phenomenon has been identified as a commonly observed process and a necessary factor to account for in isoprene algorithms (see Guenther et al., 2006, and references therein). For Stordalen mire, the $T_{48}$ function is parameterised to approach unity at the average temperature of the warmest month (approximately $12^{\circ} \mathrm{C}$; Ekberg et al., 2009). On leaf scale, Ekberg et al. (2009) had found for a pooled set of normalised data from Eriophorum and Carex growing near the flux tower similar values for $a$ and $b$, compared to our ecosystem flux parameterisation, using a larger range of $T_{48}$ from measurements over two growing seasons, which covered very low $T_{48}$ only towards the end. In their analysis, the response of the two species was not statistically different, although standardized leaf emissions in Eriophorum were overall less responsive to past temperatures. 


\section{Summary and conclusion}

Until now, long-term measurements of BVOCs at a high temporal resolution are scarce, especially in northern latitudes and from non-woody vegetation. In this study, ecosystemscale measurements of biogenic BVOCs from a sub-arctic wetland, dominated by Sphagnum, Carex and Eriophorum spp. are presented for a period that captured the entire second half of the growing season. For the first time, to our knowledge, we report ecosystem methanol fluxes from a sub-arctic wetland site. Daytime emissions observed were notable (up to ca. $270 \mu \mathrm{g} \mathrm{m}^{-2} \mathrm{~h}^{-1}$, ca. $100 \mu \mathrm{g} \mathrm{C} \mathrm{m}{ }^{-2} \mathrm{~h}^{-1}$ ), and negative fluxes directed to the surface layer appeared to occur at night. Significant emissions of isoprene were observed that were on the same order of magnitude as those published for boreal fens and forests. Standardised to common temperature, our measurements imply that the capacity of northern latitude wetland vegetation to emit isoprene may even be similar to vegetation at much lower latitudes although the strong variation of isoprene emission potential between species make such a simple comparison difficult. Still, from the emerging data from boreal and subarctic ecosystems it appears that the low emissions in these regions are mostly attributable to low temperatures rather than to low emission potential per se. For both isoprene and methanol senescence of vegetation played an important role towards the end of the growing season.

BVOC emission responses that had already been identified by Ekberg et al. (2009) at the leaf scale for the sedges growing at the Stordalen mire study site also emerged at ecosystem scale, namely a rapidly varying emission capacity in response to general weather conditions and a possibly stronger temperature-sensitivity of the fluxes compared to generally used algorithms. The commonly used Guenther et al. temperature relationship has been mostly developed and used in temperate and (sub)tropical ecosystems, and it appears also plausible that plants growing in sub-arctic environments may be more sensitive to warm temperatures. More data from a wider range of plant species growing in cold-environment ecosystems is necessary to substantiate these observations.

Long-term measurements of BVOC are still lacking for nearly all ecosystems and only very few studies on the seasonal, let alone the interannual variation of BVOC emissions have been published so far. However, such data are required for testing process understanding obtained in laboratory studies and for model evaluation. The data presented here for a sub-arctic mire ecosystem will be useful to support the development, improvement and validation of biogeochemical models to simulate the emission characteristics and ambient level of BVOCs on a regional and global scale under changing climate conditions.

Acknowledgements. This work was supported by the European Commission 6th Framework Programme, by the Marie Curie Excellence Grant MCT-ELSA and by the Swedish Research Councils VR and Formas. We would like to thank the staff of the Abisko Scientific Research Station (ANS) for their help and support as well as Ch. Spirig (Agroscope ART) for use of the ART footprint tool.

Edited by: E. Saltzman

\section{References}

Ammann, C., Brunner, A., Spirig, C., and Neftel, A.: Technical note: Water vapour concentration and flux measurements with PTR-MS, Atmos. Chem. Phys., 6, 4643-4651, 2006, http://www.atmos-chem-phys.net/6/4643/2006/.

Arneth, A., Monson, R. K., Schurgers, G., Niinemets, U., and Palmer, P. I.: Why are estimates of global isoprene emissions so similar (and why is this not so for monoterpenes)?, Atmos. Chem. Phys., 8, 4605-4620, 2008a, http://www.atmos-chem-phys.net/8/4605/2008/.

Arneth, A., Schurgers, G., Hickler, T., and Miller, P.A.: Effects of species composition, land surface cover, $\mathrm{CO}_{2}$ concentration and climate on isoprene emissions from European forests, Plant Biol., 10, 150-162, 2008b.

Atkinson, R.: Atmospheric chemistry of VOCs and $\mathrm{NO}_{\mathrm{x}}$, Atmos. Environ., 34, 2063-2101, 2000

Aubinet, M., Grelle, A., Ibrom, A., Rannik, Ü., Moncrieff, J., Foken, T., Kowalski, A. S., Martin, P. H., Berbigier, P., Bernhofer, C., Clement, R., Elbers, J., Granier, A., Grünwald, T., Morgenstern, K., Pilegaard, K., Rebmann, C., Snijders, W., Valentini, R., and Vesala, T.: Estimates of the annual net carbon and water exchange of forests: the EUROFLUX methodology, Adv. Ecol. Res., 30, 113-175, 2000.

Bäckstrand, K., Crill, P. M., Mastepanov, M., Christensen, T. R., and Bastviken, D.: Non-methane volatile organic compound flux from a subarctic mire in Northern Sweden, Tellus 60, 226-237, 2008.

Brunner, A., Ammann, C., Neftel, A., and Spirig, C.: Methanol exchange between grassland and the atmosphere, Biogeosciences, 4, 395-410, 2007, http://www.biogeosciences.net/4/395/2007/.

Custer, T. G. and Schade, G. W.: Methanol and acetaldehyde fluxes over ryegrass, Tellus, 59, 673-684, 2007.

de Gouw, J., Warneke, C., Karl, T., Eerdekens, G., van der Veen, C., and Fall, R.: Sensitivity and specificity of atmospheric trace gas detection by proton-transfer-reaction mass spectrometry, Int. J. Mass Spectrom., 223-224, 365-382, 2003.

de Gouw, J. and Warneke, C.: Measurements of Volatile Organic Compounds in the Earth's atmosphere using Proton-TransferReaction Mass Spectrometry, Mass Spectrom. Rev., 26, 223257, 2007.

Derwent, R. G, Middleton, D. R., Field, R. A., Goldstone, M. E., Lester, J. N., and Perry, R.: Analysis and interpretation of air quality data from an urban roadside location in central London over the period from July 1991 to July 1992, Atmos. Environ., 29, 923-946, 1995.

Di Carlo, P., Brune, W., Martinez, M., Harder, H., Lesher, R., Ren, X., Thornberry, T., Carroll, M. A., Young, V., Shepson, P. B., Riemer, D., Apel, E., and Campbell, C.: Missing OH reactivity in a forest: Evidence for unknown reactive biogenic VOCs, Science, 304, 722-725, 2004.

Ekberg, A., Arneth, A., Hakola, H., Hayward, S., and Holst, T.: Isoprene emission from wetland sedges, Biogeosciences, 6, 601- 
613, 2009,

http://www.biogeosciences.net/6/601/2009/.

Foken, T.: Angewandte Meteorologie, Springer Verlag, Berlin, 289 pp., 2003.

Fuentes, J. D., Wang, D., and Gu, L.: Seasonal variations in isoprene emissions from a boreal aspen forest, J. Appl. Meteorol., 38, 855-869, 1999.

Gallagher, M. W., Clayborough, R., Beswick, K. M., Hewitt, C. N., Owen, S., Moncrieff, J., and Pilegaard, K.: Assessment of a relaxed eddy accumulation for measurements of fluxes of biogenic volatile organic compounds: study over arable crops and a mature beech forest, Atmos. Environ., 34, 2887-2899, 2000.

Grabmer, W., Graus, M., Lindinger, C., Wisthaler, A., Rappenglück, B., Steinbrecher, R., and Hansel, A.: Disjunct eddy covariance measurements of monoterpene fluxes from a Norway spruce forest using PTR-MS, Int. J. Mass Spectrom., 239, 111$115,2004$.

Guenther, A. B., Zimmerman, P. R., Harley, P. C., Monson, R. K., and Fall, R.: Isoprene and monoterpene emission rate variability - Model evaluations and sensitivity analyses, J. Geophys. Res., 98, 12609-12617, 1993.

Guenther, A., Hewitt, C. N., Erickson, D., Fall, R., Geron, C., Graedel, T., Harley, P., Klinger, L., Lerdau, M., Mckay, W. A., Pierce, T., Scholes, B., Steinbrecher, R., Tallamraju, R., Taylor, J., and Zimmerman, P.: A global model of natural organic compound emissions, J. Geophys. Res.-Atmos., 100, 8873-8892, 1995.

Guenther, A.: Seasonal and spatial variations in natural volatile organic compound emissions, Ecol. Appl., 7, 34-45, 1997.

Guenther, A. , Karl, T., Harley, P., Wiedinmyer, C., Palmer, P.I., Geron, C.: Estimates of global terrestrial isoprene emissions using MEGAN (Model of Emissions of Gases and Aerosols from Nature), Atmos. Chem. Phys., 6, 3181-3210, 2006,

http://www.atmos-chem-phys.net/6/3181/2006/.

Haapanala, S., Rinne, J., Pystynen, K.-H., Hellén, H., Hakola, H., and Riutta, T.: Measurements of hydrocarbon emissions from a boreal fen using the REA technique, Biogeosciences, 3, 103-112, 2006, http://www.biogeosciences.net/3/103/2006/.

Hayward, S., Hewitt, C. N., Sartin, J. H., and Owen, S. M.: Performance characteristics and applications of a Proton Transfer Reaction-Mass Spectrometer for measuring volatile organic compounds in ambient air, Environ. Sci. Technol., 36, 15541560, 2002.

Hellén, H., Hakola, H., Pystynen, K.-H., Rinne, J., and Haapanala, S.: $\mathrm{C}_{2}-\mathrm{C}_{10}$ hydrocarbon emissions from a boreal wetland and forest floor, Biogeosciences, 3, 167-174, 2006, http://www.biogeosciences.net/3/167/2006/.

Hoffmann, T., Odum, J. R., Bowman, F., Collins, D., Klockow, D., Flagan, R. C., and Seinfeld, J. H.: Formation of organic aerosols from the oxidation of biogenic hydrocarbons, J. Atmos. Chem., 26, 189-222, 1997.

Holzinger, R., Lee, A., Paw U, K. T., and Goldstein, A. H.: Observations of oxidation products above a forest imply biogenic emissions of very reactive compounds, Atmos. Chem. Phys., 5, 67-75, 2005, http://www.atmos-chem-phys.net/5/67/2005/.

Hüve, K., Christ, M. M., Kleist, E., Uerlings, R., Niinemets, Ü., Walter, A., and Wildt, J.: Simultaneous growth and emission measurements demonstrate an interactive control of methanol release by leaf expansion and stomata, J. Exp. Botany, 58, 1783-
1793, 2007.

Jackowicz-Korczynski, M.: Land-atmosphere interactions of a subarctic palsa mire, Meddelande från Lunds Universitets Geografiska Institution, Avhandlingar, 184, 93 pp., 2009.

Janson, R., de Serves, C., and Romero, R.: Emission of isoprene and carbonyl compounds from a boreal forest and wetland in Sweden, Agric. Forest Meteorol., 98-99, 671-681, 1999.

Johansson, T., Malmer, N., Crill, P. M., Friborg, T., 'Åkerman, J.H., Mastepanov, M., and Christensen, T. R.: Decadal vegetation changes in a northern peatland, greenhouse gas fluxes and net radiative forcing, Global Change Biol., 12, 1-18, 2006.

Karl, T., Guenther, A., Jordan, A., Fall, R., and Lindinger, W.: Eddy covariance measurement of biogenic oxygenated VOC emissions from hay harvesting, Atmos. Environ., 35, 491-495, 2001.

Karl, T. G., Spirig, C., Rinne, J., Stroud, C., Prevost, P., Greenberg, J., Fall, R., and Guenther, A.: Virtual disjunct eddy covariance measurements of organic compound fluxes from a subalpine forest using proton transfer reaction mass spectrometry, Atmos. Chem. Phys., 2, 279-291, 2002,

http://www.atmos-chem-phys.net/2/279/2002/.

Karl, T., Guenther, A., Spirig, C., Hansel, A., and Fall, R.: Seasonal variation of biogenic VOC emissions above a mixed hardwood forest in northern Michigan, Geophys. Res. Lett., 30, 2186 , doi:10.1029/2003GL018432, 2003.

Karl, T., Potosnak, M., and Guenther, A.: Exchange processes of volatile organic compounds above a tropical rain forest: Implications for modelling tropospheric chemistry above dense vegetation, J. Geophys. Res., 109, D18306, doi:10.1029/2004JD004738, 2004.

Karl, T., Harley, P., Guenther, A., Rasmussen, R., Baker, B., Jardine, K., and Nemitz, E.: The bi-directional exchange of oxygenated VOCs between a loblolly pine (Pinus taeda) plantation and the atmosphere, Atmos. Chem. Phys., 5, 3015-3031, 2005, http://www.atmos-chem-phys.net/5/3015/2005/.

Karl, T., Guenther, A., Turnipseed, A., Patton, E. G., and Jardine, K.: Chemical sensing of plant stress at the ecosystem level, Biogeosciences, 5, 1287-1294, 2008, http://www.biogeosciences.net/5/1287/2008/.

Kesselmeier, J. and Staudt, M.: Biogenic volatile organic compounds (VOC): An overview on emission, physiology and ecology, J. Atmos. Chem., 33, 23-88, 1999.

Kormann, R. Meixner, F. X.: An analytical footprint model for Non-neutral Stratification, Bound.-Lay. Meteorol., 99, 207-224, 2001.

Kulmala, M., Hämeri, K., Mäkelä, J. M., Aalto, P. P., Pirjola, L., Väkeva, M., Nilsson, E. D., Koponen, I. K., Buzorius, G., Keronen, P., Rannik, Ü., Laakso, L., Vesala, T., Bigg, K., Seidl, W., Forkel, R., Hoffmann, T., Spanke, J., Janson, R., Shimmo, M., Hansson, H. C., O’Dowd, C., Becker, E., Paatero, J., Teinilä, K., Hillamo, R., Viisanen, Y., Laaksonen, A., Swietlicki, E., Salm, J., Hari, P., Altimir, N., and Weber, R.: Biogenic aerosol formation in the boreal forest, Boreal Environ. Res., 5, 281-297, 2000.

Kulmala, M., Suni, T., Lehtinen, K. E. J., Dal Maso, M., Boy, M., Reissell, A., Rannik, Ü., Aalto, P., Keronen, P., Hakola, H., Bäck, J., Hoffmann, T., Vesala, T., and Hari, P.: A new feedback mechanism linking forests, aerosols, and climate, Atmos. Chem. Phys., 4, 557-562, 2004, http://www.atmos-chem-phys.net/4/557/2004/.

Lathière, J., Hauglustaine, D. A., Friend, A. D., De Noblet- 
Ducoudré, N., Viovy, N., and Folberth, G. A.: Impact of climate variability and land use changes on global biogenic volatile organic compound emissions, Atmos. Chem. Phys., 6, 2129-2146, 2006, http://www.atmos-chem-phys.net/6/2129/2006/.

Lee, A., Schade, G. W., Holzinger, R., and Goldstein, A. H.: A comparison of new measurements of total monoterpene flux with improved measurements of speciated monoterpene flux, Atmos. Chem. Phys., 5, 505-513, 2005, http://www.atmos-chem-phys.net/5/505/2005/.

Lenschow, D. H. Raupach, M. R.: The attenuation of fluctuations in scalar concentrations through sampling tubes, J. Geophys. Res., 96, D8, 15259-15268, 1991.

Lenschow, D. H., Mann, J., and Kristensen, L.: How long is long enough when measuring fluxes and other turbulence statistics?, J. Atmos. Oceanic Technol., 11, 661-673, 1994.

Lindinger, W., Hansel, A., and Jordan, A.: On-line monitoring of volatile organic compounds at pptv levels by means of protontransfer-reaction mass spectrometry (PTR-MS) - medical applications, food control and environmental research, Int. J. Mass Spectrom. Ion Proc., 173, 191-241, 1998.

McMillen, R. T.: An Eddy-Correlation Technique with Extended Applicability to Non-Simple Terrain, Boundary-Layer Meteorol., 43, 231-245, 1988.

Neftel, A., Spirig, C., and Ammann, C.: Application and test of a simple tool for operational footprint evaluations, Environ. Poll., 152, 644-652, 2008.

Nemecek-Marshall, M., MacDonald, R. C., Franzen, J. J., Wojciechowski, C. L., and Fall, R.: Methanol emissions from leaves, Plant Physiol., 108, 1359-1368, 1995.

Niinemets, Ü., Loreto, F., and Reichstein, M.: Physiological and physicochemical controls on foliar volatile organic compound emissions, Trends Plant Sci., 9, 180-186, 2004.

O’Dowd, C. D., Jimenez, J. L., Bahreini, R., Flagan, R. C., Seinfeld, J. H., Hämeri, K., Pirjola, L., Kulmala, M., Jennings, S. G., and Hoffmann, T.: Marine aerosol formation from biogenic iodine emissions, Nature, 417, 497-501, 2002.

Ortega, J., Helmig, D., Guenther, A., Harley, P., Pressley, S., and Vogel, C.: Flux estimates and $\mathrm{OH}$ reaction potential of reactive biogenic volatile organic compounds (BVOCs) from a mixed northern hardwood forest, Atmos. Environ., 41, 54795495, 2007.

Panofsky, H. A., Tennekes, H., Lenschow, D. H., and Wyngaard, J. C.: The characteristics of turbulent velocity components in the surface layer under convective conditions, Boundary-Layer Meteorol., 11, 355-361, 1977.

Poisson, N., Kanakidou, M., and Crutzen, P. J.: Impact of NonMethane Hydrocarbons on tropospheric chemistry and the oxidizing power of the global atmosphere: 3-dimensional modelling results, J. Atmos. Chem., 36, 157-230, 2000.

Pressley, S., Lamb, B., Westberg, H., Flaherty, J., Chen, J., and Vogel, C.: Long-term isoprene flux measurements above a northern hardwood forest, J. Geophys. Res., 110, D07301, doi:10.1029/2004JD005523, 2005.

Pressley, S., Lamb, B., Westberg, H., and Vogel, C.: Relationships among canopy scale energy fluxes and isoprene flux derived from long-term, seasonal eddy covariance measurements over a hardwood forest, Agr. Forest Meteorol., 136, 188-202, 2006.

Rinne, J., Tuovinen, J.-P., Laurila, T., Hakola, H., Aurela, M., and Hypén, H.: Measurements of hydrocarbon fluxes by a gradient method above a northern boreal forest, Agric. Forest Meteorol., 102, 25-37, 2000.

Rinne, H. J. I., Guenther, A., Warnecke, C., de Gouw, J. A., and Luxembourg, S. L.: Disjunct eddy covariance technique for trace gas flux measurements, Geophys. Res. Lett., 28, 3139-3142, 2001.

Rinne, H. J. I., Guenther, A. B., Greenberg, J. P., and Harley, P. C.: Isoprene and monoterpene fluxes measured above Amazonian rainforest and their dependence on light and temperature, Atmos. Environ., 36, 2421-2426, 2002.

Rinne, J., Ruuskanen, T. M., Reissell, A., Taipale, R., Hakola, H., and Kulmala, M.: On-line PTR-MS measurements of atmospheric concentrations of volatile organic compounds in a European boreal forest ecosystem, Boreal Environ. Res., 10, 425-436, 2005.

Rinne, J., Taipale, R., Markkanen, T., Ruuskanen, T. M., Hellén, H., Kajos, M. K., Vesala, T., and Kulmala, M.: Hydrocarbon fluxes above a Scots pine forest canopy : measurements and modeling, Atmos. Chem. Phys., 7, 3361-3372, 2007, http://www.atmos-chem-phys.net/7/3361/2007/.

Schade, G. W. and Goldstein, A. H.: Fluxes of oxygenated volatile organic compounds from a ponderosa pine plantation, J. Geophys. Res., 106, 311-3123, 2001.

Schade, G. W. and Custer, T. G.: OVOC emissions from agricultural soil in northern Germany during the 2003 European heat wave, Atmos. Environ., 38, 6105-6114, 2004.

Schuepp, P. H., Leclerc, M. Y., MacPherson, J. I., and Desjardins, R. L.: Footprint prediction of scalar fluxes from analytical solutions of the diffusion equation, Boundary-Layer Meteorol., 50, 355-373, 1990.

Seco, R., Peñuelas, J., and Filella, I.: Short-chain oxygenated VOCs: Emission and uptake by plants and atmospheric sources, sinks, and concentrations, Atmos. Environ., 41, 2477-2499, 2007.

Simon, E., Meixner, F. X., Rummel, U., Ganzevelt, L., Ammann, C., and Kesselmeier, J.: Coupled carbon-water exchange of the Amazon rain forest, II. Comparison of predicted and observed seasonal exchange of energy, $\mathrm{CO}_{2}$, isoprene and ozone at a remote site in Rondônia, Biogeosciences, 2, 255-275, 2005, http://www.biogeosciences.net/2/255/2005/.

Singh, S. and Li, Z.: Kinetics investigation of $\mathrm{OH}$ reaction with isoprene at 240-340 K and 1-3 Torr using Relative Rate/Discharge Flow/Mass Spectrometer Technique, J. Phys. Chem. A, 111, 11843-11851, 2007.

Spirig, C., Neftel, A., Ammann, C., Dommen, J., Grabmer, W., Thielmann, A., Schaub, A., Beauchamp, J., Wisthaler, A., and Hansel, A.: Eddy covariance flux measurements of biogenic VOCs during ECHO 2003 using proton transfer reaction mass spectrometry, Atmos. Chem. Phys., 5, 465-481, 2005, http://www.atmos-chem-phys.net/5/465/2005/.

Ström, L. and Christensen, T. R.: Below ground carbon turnover and greenhouse gas exchanges in a sub-arctic wetland, Soil Biol. Biochem., 39, 1689-1698, 2007.

Svensson, B. H., Christensen, T. R., Johansson, E., and Öquist, M.: Interdecadal Changes in $\mathrm{CO}_{2}$ and $\mathrm{CH}_{4}$ Fluxes of a Subarctic Mire: Stordalen Revisited after 20 Years, Oikos, 85, 22-30, 1999.

Thomas, C. and Foken, T.: Re-evaluation of integral turbulence characteristics and their parameterisations. Proc. $15^{\text {th }}$ Confer- 
ence on Turbulence and Boundary Layers, Wageningen, NL, Am. Meteorol. Soc., 129-132, 2002.

Tiiva, P., Rinnan, R., Holopainen, T., Mörsky, S. K., and Holopainen, J. K.: Isoprene emissions from boreal peatland microcosms; effects of elevated ozone concentration in an open field experiment, Atmos. Environ., 41, 3819-3828, 2007a.

Tiiva, P., Rinnan, R., Faubert, P., Räsänen, J., Holopainen, T., Kyrö, E., and Holopainen, J. K.: Isoprene emission from a subarctic peatland under enhanced UV-B radiation, New Phytol., 176, 346-355, 2007b.

Tunved, P., Hansson, H. C., Kerminen, V.-M., Ström, J., Dal Maso, M., Lihavainen, H., Viisanen, Y., Aalto, P. P., Komppula, M., and Kulmala, M.: High natural aerosol loading over boreal forests, Science, 312, 261-263, 2006.

Warneke, C., de Gouw, J. A., Kuster, W. C., Goldan, P. D., and Fall, R.: Validation of atmospheric VOC measurements by Proton-Transfer Reaction Mass Spectrometry using a gaschromatographic preseparation method, Environ. Sci. Technol., 37, 2494-2501, 2003.
Westberg, H., Lamb, B., Kempf, K., and Allwine, G.: Isoprene emission inventory for the BOREAS southern study area, Tree Physiol., 20, 735-743, 2000.

Wienhold, F. G., Welling, M., and Harris, G. W.: Micrometeorological measurement and source region analysis of nitrous oxide fluxes from an agricultural soil, Atmos. Environ., 29, 2219-2227, 1995.

Wilson, J. D. and Swaters, G. E.: The source area influencing a measurement in the planetary boundary layer: The 'footprint' and the "distribution of contact distance", Boundary-Layer Meteorol., 55, 25-46, 1991. 